University of Wollongong

Research Online

Faculty of Business - Papers (Archive)

Faculty of Business and Law

$1-1-2017$

Evaluating airline operational performance: A Luenberger-Hicks-Moorsteen productivity indicator

Juergen Heinz Seufert

University of Nottingham China Campus, juergen@uow.edu.au

Amir Arjomandi

University of Wollongong, amira@uow.edu.au

K Herve Dakpo

INRA, France

Follow this and additional works at: https://ro.uow.edu.au/buspapers

Part of the Business Commons

Research Online is the open access institutional repository for the University of Wollongong. For further information contact the UOW Library: research-pubs@uow.edu.au 


\title{
Evaluating airline operational performance: A Luenberger-Hicks-Moorsteen productivity indicator
}

\author{
Abstract \\ This study proposes a by-production Luenberger-Hicks-Moorsteen indicator that includes undesirable \\ outputs, here $\mathrm{CO} 2$ emissions, in airline performance analysis. We use capital and staff as inputs and \\ tonne-kilometres available as a desirable output to evaluate operation stage efficiency and productivity of \\ the world's major airlines between 2007 and 2013. Our results demonstrate European airlines are \\ relatively stronger performers in terms of both pollution-adjusted operational efficiency and productivity. \\ Middle-Eastern airlines have made gains in terms of output growth but perform poorly in terms of \\ pollution-adjusted productivity, evidence that ETSs may produce greener airlines. \\ Disciplines \\ Business

\section{Publication Details} \\ Seufert, J. H., Arjomandi, A. \& Dakpo, K. Herve. (2017). Evaluating airline operational performance: A \\ Luenberger-Hicks-Moorsteen productivity indicator. Transportation Research Part E: Logistics and \\ Transportation Review, 104 52-68.
}




\title{
Evaluating airline operational performance: A Luenberger-Hicks-Moorsteen productivity indicator
}

\begin{abstract}
This study proposes a by-production Luenberger-Hicks-Moorsteen indicator that includes undesirable outputs, here $\mathrm{CO}_{2}$ emissions, in airline performance analysis. We use capital and staff as inputs and tonne-kilometres available as a desirable output to evaluate operation stage efficiency and productivity of the world's major airlines between 2007 and 2013. Our results demonstrate European airlines are relatively stronger performers in terms of both pollution-adjusted operational efficiency and productivity. Middle-Eastern airlines have made gains in terms of output growth but perform poorly in terms of pollution-adjusted productivity, evidence that ETSs may produce greener airlines.
\end{abstract}

Keywords: Data envelopment analysis, airlines, by-production, emissions, Luenberger-HicksMoorsteen.

JEL Classification: D21, C61, Q53

\section{Introduction}

The US Environmental Protection Agency (EPA) stated recently that 'greenhouse gas emissions from airplanes are dangerous to human life', and therefore should be subject to further emission-reducing regulations (EPA, 2015, p. 1). In addition to the immediate threat to human lives, the Intergovernmental Panel on Climate Change (IPCC) has forecast that aviation emissions will make an important contribution to the build-up of greenhouse gases (GHGs) in the atmosphere, heavily contributing to global warming in the next few decades (IPCC, 2007). Consequently, over the past few years, national and international attempts to curb climate change have forced governments to implement strategies to reduce anthropocentric $\mathrm{CO}_{2}$ (carbon dioxide) emissions in general, and by the aviation industry in particular. As significant users of fossil fuels, airline industries have been included in planned and operational emission trading schemes (ETSs) in several jurisdictions across the world. They were considered for inclusion in the first phase of the European ETS in January 2005. In January 2012 it became the first trading scheme to cover $\mathrm{CO}_{2}$ emissions from air travel, quickly followed by Australia and New Zealand in July 2012. In China, the Shanghai ETS included six major airlines, making them subject to a price on carbon from November 2013 onwards. In January 2015, another Asian country, South Korea, started its ETS covering six GHGs with a 30 per cent reduction target until 2020 and planned to put a price on emission from airlines. In the US, the mandatory trading under the RGGI (Regional Greenhouse Gas Initiative) founded in 2009 has, since 2013, included in the voluntary trading within the Western Climate Initiative (WCI) with the potential inclusion of airlines in British Columbia, California, Manitoba, Ontario and Quebec. In 2012, the US EPA also announced that market-based measures (MGMs) against aviation emissions need to be taken, but left 
the design of such measures to the International Civil Aviation Organization (ICAO). ${ }^{1}$ Currently, several other countries (such as Brazil, Chile, Japan, Mexico, Russia, Turkey, Ukraine and Vietnam) have also considered an ETS as a viable solution to reduce their carbon footprint, indicating a substantial growth in ETSs worldwide that put a price on GHGs emission and require airlines to surrender permits equivalent to their footprint (ICAP, 2015). Coinciding with the establishment of ETSs, increases in fuel prices have provided additional incentives for airlines to reduce their carbon footprints, because fuel is among the top three cost items faced by airlines, accounting on average for up to one-third of their operating costs in 2013 and 20 per cent in 2016 depending on the price of Jet A/A-1 fuel (IATA, 2013; 2016). Airlines may respond to these new higher cost regulatory and economic environments by upgrading their fleet and introducing more fuel-efficient models, and adjusting operating practices to reduce fuel consumption and thus ease the financial burden (Sgouridis et al., 2011). In this context, it is pertinent and timely to produce a precise measure of airline performance. This study proposes a novel productivity indicator to measure airline pollution-adjusted operational efficiency and productivity changes. This measure can provide crucial findings and help policy makers to better understand the environmental performance of their national carriers (vis-à-vis their rivals) and gain a deeper insight into the effectiveness of ETSs in reducing airline emissions in different regions. This new indicator can also assist airlines understand their relative pollutionadjusted performance in order to eliminate existing shortcomings. Moreover, eco-conscious travelers may find our findings helpful to help them select services from more environmentally friendly airlines and so reduce their own carbon footprint.

In the non-parametric framework of data envelopment analysis (DEA), a common approach to analysing the relationships between multiple inputs and outputs and evaluating the relative efficiency of decision-making units (here, airlines), many models have been developed to account for undesirable outputs. ${ }^{2}$ In these models, pollution has commonly been treated as an output under the weak disposability assumption, WDA (Färe et al., 1986; 1989). Although this approach has been widely used in both energy (Zhou et al., 2008; Chen, 2013a) and airline efficiency literature (e.g., Fukuyama et al., 2011; Chang et al., 2014; Li et al., 2016a), clear limits of this approach have been put forward in several studies (Førsund, 2009; Chen, 2013b). Among others, the WDA violates the materials balance principle which ensures every physical process occur within the limits of the laws of thermodynamics (Coelli et al., 2007). The by-production approach, introduced by Murty et al. (2012), is considered in the literature as a better alternative for avoiding such drawbacks (Chambers et al., 2014; Serra et al., 2014). This approach posits that complex systems are made of several independent processes (Frisch, 1965 ) and the global technology can be separated into sets of sub-technologies: one for the production

\footnotetext{
${ }^{1}$ We would like to thank the anonymous reviewer for pointing out that non-market based solutions, e.g. technology standards, aircraft engine and technology improvements measures, had already been adopted by the US Government (FAA, 2012).

${ }^{2}$ DEA was first introduced by Charnes et al. (1978), after Farrell (1957) proposed the original idea of efficiency evaluation.
} 
of good outputs and one for the generation of bad outputs. In other words, the by-production approach draws on an explicit representation of the process that generates each type of output (good and detrimental outputs in this case). Then, the global technology implies interactions between several separate sub-technologies. Førsund (2017) has recently classified the by-production approach among the multi-equation modelling approaches and argued that an important advantage of this approach over other approaches (such as WDA, the strong disposability assumption and the slack-based models) is that it represents pollution-generating technologies by accounting for materials balance and therefore satisfies the physical laws. Discussing the limits of pollution-generating technologies, Dakpo et al. (2016) also confirmed that the by-production method offers some very promising opportunities, such as treating multiple types of outputs, in comparison to other existing approaches. Therefore, this study employs the by-production approach and also contributes to the efficiency analysis literature by offering a new by-production model which deals with the inclusion of undesirable outputs to provide a comprehensive analysis of operational performance of 33 major international airlines for the period 2007 to 2013.

In the area of productivity analyses, the Malmquist index is by far the most popular index for assessing the productivity of decision-making units (DMUs) over time, though it has several shortcomings (Arjomandi, 2011; Arjomandi \& Seufert, 2014; Kerstens \& Van de Woestyne, 2014; Arjomandi et al., 2015). O'Donnell (2008) argues that an adequate productivity index must be multiplicatively or additively complete. That is, a total factor productivity index (TFP) should be written as the ratio of an aggregate output to an aggregate input (multiplicative completeness) or as the difference of these aggregate values (additive completeness). Besides, TFP indices must satisfy a certain number of axioms and tests; monotonicity, homogeneity, identity, dimensionality, proportionality, time-reversal, factor-reversal and circularity tests are among the 20 key tests listed by Diewert (1992). However, the Malmquist index fails to satisfy these conditions. The Hicks-Moorsteen (HM) index, discussed in Bjurek (1996) and Lovell (2003), is proven to be a complete index (O’Donnell, 2008; 2010; 2012). ${ }^{3}$ In this study, in addition to the above-mentioned contribution, we extend the Luenberger-HicksMoorsteen (LHM) productivity indicator of Briec and Kerstens (2004) to account for undesirable outputs in the framework of the by-production approach. The directional distance function (DDF) used in this study has the advantage of allowing for simultaneous changes in both good and bad outputs (Chung et al., 1997). Moreover, unlike the Malmquist index, our difference-based indicator possesses the advantage of dealing with zero and negative variables and also inherits of the translation invariance property.

In sum, this study develops a novel approach that incorporates undesirable outputs in the production technology modelling to measure DMU inefficiency and productivity changes in general, and airline

\footnotetext{
${ }^{3}$ This HM index is based on the ratios of Malmquist output and input productivity indices.
} 
performance in particular. This new indicator is inspired by the environmental performance index of Färe et al. (2004) which was presented as a ratio of a Malmquist good output quantity index over a Malmquist bad output quantity index. Our approach, however, is difference-based and we use the byproduction approach to model pollution-generating technologies and also avoid theoretical and practical issues of the WDA and the Malmquist productivity index as discussed above. Our developed by-production LHM productivity indicator also allows us to decompose the pollution-adjusted TFP more comprehensively into the good and the bad output components providing further insight into our understanding of airline operational performance.

The paper is structured as follows: Section 2 outlines existing institutional and regulatory frameworks relevant to the study. Section 3 reviews the literature. The methodology and data are presented in Section 4. Section 5 discusses the results, followed by some concluding remarks in Section 6.

\section{Regulatory framework: international emission trading schemes}

On an international scale the ICAO (International Civil Aviation Organization) is in sole authority for setting out measures to reduce aviation emissions in a globally consistent and binding way. Directly after the ICAO rejected the Europeans' attempts to put a price on emissions of the flights from and to Europe, the 38th assembly decided to introduce a cap-and-trade-based scheme for the aviation industry by 2020 in line with its voluntary goal to reduce aviation emissions by 50 per cent by 2050 (IATA, 2016). The European emission trading scheme (EU ETS) included emissions from flights starting or landing in Europe including those beyond the EU territory, from 2012 onwards. However, opposition from China, India, Russia and the US amongst others forced the EU, in April 2013, to constrain the ETS operation to the flights within European countries only.

In the US, there had been a voluntary trading program from 2003 to 2010, named the Chicago Climate Exchange. Besides this voluntary emission trading program, airlines faced mandatory inclusion in an ETS in 2007 when the Lieberman-Warner Climate Security Bill was approved by the US Senate Committee of Environment and Public Works. Although this Bill aimed to create an ETS across the country and included aviation industry emissions, it was aborted under pressure from the Republicans (Gössling et al., 2008). In November 2012, the then US President Obama signed a law opposing the EU-ETS with bilateral support as both parties considered the EU ETS an unilateral and illegitimate tax . Since the failure of the climate actions at a national level, regional cap and trade mechanisms were implemented in the US. Thus, the RGGI (Regional Greenhouse Gas Initiative) was founded in 2009 as a mandatory ETS membered by Connecticut, Delaware, Maine, Maryland, Massachusetts, New Hampshire, New York, Rhode Island and Vermont. In addition, the Western Climate Initiative was founded as a voluntary ETS by California in 2007 and brings together British Columbia, California, Manitoba, Ontario and Quebec, and implemented an ETS in 2012 which started 2013. Even though the members of the WCI have high reduction goals, emissions from airlines have so far 
been excluded in their schemes. In 2015, the Environmental Protection Agency (EPA) announced that greenhouse gas emissions from airplanes are a health hazard and should be regulated under the Clean Air Act. The EPA has not yet determined the design of an American ETS, but has deferred to ongoing deliberations by ICAO on the issue (EPA, 2015). At the same time the EPA has established domestic standards and limitations on exhaust emissions for any aircraft engines in the US which are enforced by the US Federal Aviation Administration (FAA).

In the Asia-Pacific region, Australia introduced an ETS in July 2012 which also applied to domestic flights. But the change to a Liberal government also opened the way for legislation to abolish a price on carbon in July 2014 (Australian Government, 2014). China, currently the largest $\mathrm{CO}_{2}$ emitter, implemented an ETS in five cities and two provinces as pilot areas before the planned nationwide ETS comes into force in 2017. Out of these seven pilot ETSs, only the Shanghai ETS includes emissions from aviation sectors, which makes six major airlines subject to a price on $\mathrm{CO}_{2}$ (Yang \& Zhao, 2015; Zhang, 2015). Japan also chose to implement an ETS in 2010. Initially, the Tokyo Metropolitan Government launched a mandatory ETS preceded by two phases of voluntary trading spanning 20022009. This ETS covers transportation emissions but until now it has not included the aviation sector, however, a national voluntary ETS aims to familiarise companies with emission trading (Bureau of Environment Tokyo Metropolitan Government, 2012). Finally, in January 2015, Korea introduced an ETS covering six GHGs and again, the aviation sector is not included (Cho, 2012; Reklev, 2015). A summary of the above-mentioned ETSs are provided in Table 1.

Table 1. Summary of the planned and established ETSs

\begin{tabular}{|c|c|c|}
\hline Jurisdiction & Milestones & Obligation \\
\hline $\begin{array}{l}\text { Europe (all } 28 \text { EU countries plus } \\
\text { Iceland, Liechtenstein and } \\
\text { Norway) }\end{array}$ & $\begin{array}{l}\text { - Phase } 1 \text { (2005-2007), during } 2007 \text { considerations to include } \\
\text { aviation emission. } \\
\text { Phase } 2 \text { (2008-2012), beginning of } 2012 \text { inclusion of aviation } \\
\text { emission from domestic (within Europe) and international (start or } \\
\text { landing in Europe) flights. } \\
\text { Phase } 3 \text { (2013-2020), due to pressure from other nations, in April } \\
\text { 2013, the EU limits the ETS to flights with start and landing in } \\
\text { Europe. }\end{array}$ & $\begin{array}{l}\text { Mandatory } \\
\text { Mandatory }\end{array}$ \\
\hline USA/North America & $\begin{array}{l}\text { - } 2003 \text { to 2010, Chicago Climate Exchange } \\
\text { 2007 Lieberman-Warner Climate Security Bill - airlines face } \\
\text { inclusion into an ETS; aborted in } 2008 \\
\text { - } 2012 \text { President Obama signs a law opposing the EU-ETS } \\
2009 \text { RGGI (Regional Greenhouse Gas Initiative) was founded } \\
\text { (Connecticut, Delaware, Maine, Maryland, Massachusetts, New } \\
\text { Hampshire, New York, Rhode Island and Vermont). Included the } \\
\text { power sector only. } \\
\text { 2013 Western Climate Initiative, (British Columbia, California, } \\
\text { Manitoba, Ontario and Quebec,) } \\
\text { 2015, the EPA announced that GHG emissions from airplanes are a } \\
\text { health hazard and should be regulated under the Clean Air Act. }\end{array}$ & $\begin{array}{l}\text { Voluntary } \\
\text { Mandatory }\end{array}$ \\
\hline Australia & $\begin{array}{l}\text { - } 2012 \text { introduction of an ETS, also covering airlines } \\
\text { - } 2014 \text { repeal of ETS }\end{array}$ & Mandatory \\
\hline China & $\begin{array}{l}\text { - } 7 \text { pilot ETSs, only the Shanghai ETS includes emissions from } \\
\text { aviation sectors }\end{array}$ & Mandatory \\
\hline Japan & - 2010 introduction of an ETS not covering airlines & Mandatory \\
\hline South Korea & - 2015 introduction of an ETS not covering airlines & Mandatory \\
\hline Internationally & - 2020 introduction of an ETS, mandated by ICAO & $\begin{array}{l}\text { To be } \\
\text { confirmed }\end{array}$ \\
\hline
\end{tabular}


Overall, there is a mix of mandatory and voluntary ETSs promoting airlines' $\mathrm{CO}_{2}$ emissions reduction or waiting for an international solution by the ICAO. Depending on the respective national or regional context, there is also diverging pressure on airlines to either reduce or bear the cost of $\mathrm{CO}_{2}$ emissions. Consequently, it can be questioned whether airlines from different regions have improved their performance accordingly.

\section{Literature Review}

There exists a number of previous studies on airline efficiency and productivity which utilise different approaches to investigate airline performance. We first summarise the literature on analysing airline efficiency and then review studies on airline productivity.

Most of the early studies on airline efficiency applied quantitative methods such as regression models (Morrell \& Taneja, 1979), cost functions (e.g., Caves et al., 1981, 1984; Windle, 1991; Baltagi et al., 1995) and stochastic frontier models (e.g., Schmidt \& Sickles, 1984; Cornwell et al., 1990; Good et al., 1993; Coelli et al., 1999). DEA-based methods became relatively more common in analysing airline performance after Schefczyk (1993) used a standard DEA for evaluating the efficiency of 15 international airlines during period 1989-1992 (Cui et al., 2016b). Few airline studies, such as Capobianco and Fernandez (2004), Bhadra (2009), Hong and Zhang (2010), Ouellette et al. (2010) and Wang et al. (2011), directly applied such standard DEA models in their analyses of efficiency. A number of studies however employed DEA models along with other techniques to examine airline efficiency. Examples include Good et al. (1995) and Alam and Sickles (1998; 2000) which combined DEA with stochastic frontier approach, free disposal hull and full disposal hull, respectively. Chiou and Chen (2006), Barros and Peypoch (2009), Greer (2009; 2016), Merkert and Hensher (2011) and Lee and Worthington (2014) were also among the studies which used DEA analysis with a regression in the second stage to explain efficiency drivers. ${ }^{4}$

In recent years, network DEA models of Li et al. (2015), Mallikarjun (2015), Li et al. (2016a), Cui and Li (2016) and Cui et al. (2016c), and dynamic models of Cui et al. (2016a; 2016b), Li et al. (2016b) and Wanke and Barros (2016) have been the core methods of assessing airline performance. With regard to network studies, Mallikarjun (2015) and Li et al. (2015) divided the network structure of airline efficiency into three stages: operations, services and sales. Mallikarjun (2015) applied a radial unoriented DEA network method to assess US airline performance in 2012. Li et al. (2015) applied the idea of virtual frontier to the network model and proposed a non-radial virtual frontier slack-based

\footnotetext{
${ }^{4}$ An extended survey of airlines' studies can be found in Table 1 in Li et al. (p.3, 2015) where the authors have also summarized the number of observations along with the methodology used.
} 
measure to evaluate energy efficiency of 22 international airlines from 2008 to 2012. Li et al. (2016a) and Cui et al. (2016c) adopted the network slack based measure (SBM) and network range-adjusted measure, respectively, to investigate the impact of EU policies on airline performance. Cui and $\mathrm{Li}$ (2016) studied airline energy efficiency with network structure and divided the efficiency process into two operations and carbon abatement stages. They built a network SBM to evaluate these efficiencies. In the most recent study of network DEA models, Xu and Cui (2017) focused further on the internal process of the airline operation system using a four-stage network structure of airline energy efficiency (i.e. Operations Stage, Fleet Maintenance Stage, Services Stage and Sales Stage). They employed a new integrated approach with network epsilon-based measure and network SBM to evaluate the overall energy efficiency and divisional efficiency of 19 international airlines in period 2008 to 2014 . With regard to dynamic models, Li et al. (2016b) developed the virtual frontier dynamic range adjusted measure (VDRAM) upon the classic DEA models and considered the capital stock as the dynamic factor or the carryover effect to be used. Wanke and Barros (2016) adopted the VDRAM of Li et al. (2016b) to measure efficiency of Latin American airlines. They also assessed the impact of different contextual variables related to cargo type, ownership type, and fleet mix on their efficiency levels. Cui et al. (2016a) improved the VDRAM of Li et al. (2016b) and introduced virtual frontier dynamic slack-based measure in order to measure airline energy efficiency and discuss the impacts of some external factors. Cui et al. (2016b) proposed two dynamic environmental DEA models to discuss the impacts of the emission limits on airline performance under circumstances that emissions are either regulated or unregulated.

Among the previous studies on airline efficiency very few have taken aviation emissions into account. Arjomandi and Seufert (2014) used carbon dioxide equivalent $\left(\mathrm{CO}_{2}-\mathrm{e}\right)$ emission as an undesirable output in their DEA models to examine environmental efficiency of the world's major airlines between 2007 and 2010. They employed bootstrapped DEA models with a strong disposability assumption to rank the airlines. Chang et al. (2014) examined the environmental efficiency of 27 global airlines in 2010 using a slacks-based measure DEA model with the weak disposability assumption. Cui and $\mathrm{Li}$ (2015), proposed the virtual frontier benevolent DEA cross efficiency model (VFB-DEA) to calculate the energy efficiencies of 11 airlines in period 2008 to 2012 They used a $\mathrm{CO}_{2}$ emissions decrease index as a proxy for undesirable output in their VFB-DEA model assuming strong disposability. Using the network SBM and network range-adjusted measure with both weak and strong disposability assumptions and considering greenhouse gas emissions as an undesirable output, Cui et al. (2016c) and Li et al. (2016a) found weak disposability results more reasonable in the aspect of distinguishing airline efficiency and establishing airlines ranking. Therefore, in their two-stage operating framework, Cui and $\mathrm{Li}$ (2016) used weak disposability to examine airline energy efficiency employing the network SBM. Cui et al. (2016b) also followed the finding of Cui et al. (2016c) and Li et al. (2016a) and utilised the weak disposability assumption in their new dynamic environmental 
DEA models. However, the weak disposability assumption, as underlined earlier, has been criticised by several studies for its disadvantages. ${ }^{5}$

Early analyses on airline productivity applied approaches such as the multilateral TFP index (Caves et al., 1981; Windle, 1991; Oum and Yu, 1995), decompositions/developments of TFP growth (Bauer, 1990; Ehrlich et al., 1994) and Fisher productivity index (Ray and Mukhrejee, 1996). The Malmquist TFP index, which is a DEA-based approach allowing for the measurement of changes in productivity of decision making units over time has been by far the most popular method adopted in the literature on airlines' TFP. Distexhe and Perelman (1994) were the first who employed the Malmquist TFP index and reported the productivity change and its two decompositions (efficiency change and technological change) for 33 US and European airlines over period 1977-1988. Subsequently, the Malmquist index was employed by Sickles et al (2002) and Greer (2008) to examine productivity change of 16 European airlines and eight US airlines, respectively. In addition, Chow (2010) used the Malmquist index to measure productivity changes in Chinese private and state-owned airlines and Cui and $\mathrm{Li}$ (2015) adopted this index to calculate the civil aviation safety efficiency of ten Chinese airlines. Assaf (2011) employed the bootstrapped Malmquist index for measuring the changes in efficiency and productivity of 18 major UK airlines between 2004 and 2007. Recently, Yang and Wang (2016) also applied the bootstrapped Malmquist index to assess airlines in four different regions in Europe. Barros and Couto (2013) used Malmquist TFP index as well as the Luenberger productivity indicator to evaluate productivity changes of European airlines from 2000 to 2011. Lee et al. (2015) has measured productivity growth of airlines when undesirable output production is incorporated into the model using the Malmquist-Luenberger productivity index. They argued that "pollution abatement activities of airlines lowers productivity growth, which suggests that the traditional approach of measuring productivity growth, which ignores $\mathrm{CO}_{2}$ emissions, overstates 'true' productivity growth" Lee et al. (2015, p.338). More recently, Lee et al. (2016) have used the Luenberger indicator to measure and decompose productivity of 34 worldwide airlines companies in the presence of $\mathrm{CO}_{2}$ emissions. $\mathrm{Bad}$ outputs are considered under the WDA in this latter study.

$\mathrm{Yu}$ (2016, p.11) conducted a survey of alternative methodologies and empirical analyses for airline performance and concluded that "environmental efficiency now becomes an important area of airline productivity and efficiency studies, focusing on $\mathrm{CO}_{2}$ emission as a negative or undesirable output." This paper builds upon this body of literature by offering additional insights on the inclusion of undesirable output in the efficiency and productivity measurement of airlines. For this aim we propose a by-production Luenberger-Hicks-Moorsteen productivity indicator. The Hicks-Moorsteen TFP index is proven to be more accurate than the popular Malmquist TFP index which is widely used in the literature. In a comprehensive comparison of the Malmquist index and Hicks-Moorsteen index,

\footnotetext{
${ }^{5}$ See Dakpo et al. (2016) for a thorough discussion on these limits.
} 
Kerstens and Van de Woestyne (2014, p.756) clearly state: "As to the question whether the Malmquist and Hicks-Moorsteen indices are empirically indistinguishable or not, the differences between both primal productivity indices turn out to be significantly different for all flexible returns to scale technology specifications." Kerstens and Van de Woestyne (2014, p.756) also state that "if one wants to be on the safe side, then one conclusion is that in case the interest centers on TFP measurement it is probably wise to immediately opt for the Hicks-Moorsteen index." In regard to modelling pollutiongenerating technologies, the by-production method of including undesirable output is also argued to be better and more reliable than those methods which are assuming strong or weak disposability assumptions. This study is the first applying such a comprehensive indicator which is a combination of both the by-production approach and the Hicks-Moorsteen productivity index using Luenberger directional distance functions.

Overall, this study contributes to the efficiency and productivity literature in general, and airline performance analysis in particular, by introducing a new indicator and including an undesirable output in the Hicks-Moorsteen TFP index. In addition, we have decomposed this indicator into good and bad output components which allow us to measure the combined effect of good and bad efficiency change. Therefore, in this paper, instead of focussing on classical decomposition of TFP indicators into technical and efficiency change, our decomposition stresses the changes in the different outputs, the goods and the bads. This choice is guided by the aim at providing a direct decomposition of a pollution-adjusted productivity indicator. The good output component provides information on the managerial ability of DMUs (here airlines) in producing more desirable outputs given their input consumption, and the bad output provides insights into the possibility of decreasing detrimental outputs like pollution based on inputs and states of the environment (in terms of policy for instance). Practically this decomposition can help us identifying companies that take advantage of both or only one of the components.

\section{Methodology and data}

\subsection{Methodology}

Formally, let $x$ represents a vector of inputs $\left(x \in \mathbb{R}_{+}^{K}\right)$, y a vector of good outputs $\left(\mathrm{y} \in \mathbb{R}_{+}^{\mathrm{Q}}\right), b$ denotes a vector of bad outputs $b \in \mathbb{R}_{+}^{R}$, and $N$ the number of DMUs. To work it out, Murty et al. (2012) split the input vector into two groups: non-pollution causing inputs $\left(x_{1}\right)$ and pollution-generating inputs $\left(x_{2}\right)$.

\section{The by-production technology}

The global technology is the intersection of the following two sub-technologies: production of good outputs and generation of bad outputs. 


$$
\Psi=\Psi_{1} \cap \Psi_{2}
$$

In the non-parametric framework of DEA the different sub-technologies can be represented under variable returns to scale (VRS) as:

$$
\begin{gathered}
\Psi_{1}=\left[\left(x_{1}, x_{2}, y, b\right) \in \mathbb{R}^{K+Q+R} \mid \sum_{n=1}^{N} \lambda_{n} x_{1 n} \leq x_{1} ; \sum_{n=1}^{N} \lambda_{n} x_{2 n} \leq x_{2} ; \sum_{n=1}^{N} \lambda_{n} y_{n}\right. \\
\left.\geq y ; \sum_{n=1}^{N} \lambda_{n}=1\right]
\end{gathered}
$$

and

$$
\Psi_{2}=\left[\left(x_{1}, x_{2}, y, b\right) \in \mathbb{R}^{K_{1}+K_{2}+Q+R} \mid \sum_{n=1}^{N} \mu_{n} x_{2 n} \geq x_{2} ; \sum_{n=1}^{N} \mu_{n} b_{n} \leq b ; \sum_{n=1}^{N} \mu_{n}=1\right]
$$

Then Murty et al. (2012) propose to represent the global technology as follows:

$$
\begin{gathered}
\Psi=\left[\left(x_{1}, x_{2}, y, b\right) \in \mathbb{R}^{K_{1}+K_{2}+Q+R} \mid \sum_{n=1}^{N} \lambda_{n} x_{1 n} \leq x_{1} ; \sum_{n=1}^{N} \lambda_{n} x_{2 n}\right. \\
\leq x_{2} ; \sum_{n=1}^{N} \lambda_{n} y_{n} \geq y ; \sum_{n=1}^{N} \lambda_{n}=1 ; \sum_{n=1}^{N} \mu_{n} x_{2 n} \\
\left.\geq x_{2} ; \sum_{n=1}^{N} \mu_{n} b_{n} \leq b ; \sum_{n=1}^{N} \mu_{n}=1\right]
\end{gathered}
$$

In model (4) the two sub-technologies are represented with two distinct intensity (structural) variables $(\lambda, \mu)$. These variables are the weights assigned to each DMU in the benchmark (reference set) of a DMU under evaluation. For global technology, the good outputs and the non-pollution-causing inputs verify the free (strong) disposability assumption; that is, if any non-pollution-causing input is increased (whether proportionally or not), (good) outputs do not decrease. On the good outputs side, the strong disposability states that it is possible to produce less with the same levels of inputs. The bad 
outputs satisfy the assumption of "costly disposability", which implies that it is possible to pollute more with the same levels of polluting inputs. ${ }^{6}$

\section{Luenberger-Hicks-Moorsteen (LHM) pollution-adjusted productivity indicator}

Given the particular nature of the by-production approach, we need to adapt the LHM index to properly fit with the existence of two independent sub-technologies. Following the work of Briec and Kerstens (2004), we propose an indicator that is output oriented and measures the difference between two Luenberger quantity indicators. For the period $t$ we have

$$
L H M_{t}=L G_{t}-L B_{t}
$$

In Equation (5) we define the pollution-adjusted LHM indicator as the difference between the Luenberger productivity indicator for the good outputs $(L G)$ and the Luenberger productivity indicator for the bad outputs $(L B)$.

$L G_{t}$ is defined in Equation (6) as the changes in good outputs production from year $t$ to $t+1$ using the inputs and bad outputs levels of period $t$. When $L G_{t}>0$, it means that from $t$ to $t+1$, using the inputs and bad outputs levels of period $t$, the DMU under evaluation has improved its efficiency:

$$
L G_{t}=D^{t}\left(x^{t}, y^{t}, b^{t} ;\left(0, g_{G}^{t}, 0\right)\right)-D^{t}\left(x^{t}, y^{t+1}, b^{t} ;\left(0, g_{G}^{t+1}, 0\right)\right)
$$

Similarly, on the bad output side we have

$$
L B_{t}=D^{t}\left(x_{2}{ }^{t}, y^{t}, b^{t+1} ;\left(0,0, g_{B}^{t+1}\right)\right)-D^{t}\left(x_{2}{ }^{t}, y^{t}, b^{t} ;\left(0,0, g_{B}^{t}\right)\right.
$$

Here, values greater than zero expresses productivity losses, while values lower than zero corresponds to productivity gains.

In Equations (6) and (7) $g_{G}^{t}, g_{B}^{t}$ are directional vectors used to assess the inefficiency.

Similarly, the LMH can also be estimated for period $t+1$ :

\footnotetext{
${ }^{6}$ See Murty (2010) for more discussion on this assumption.
} 


$$
L G_{t+1}=D^{t+1}\left(x^{t+1}, y^{t}, b^{t+1} ;\left(0, g_{O}^{t}, 0\right)\right)-D^{t+1}\left(x^{t+1}, y^{t+1}, b^{t+1} ;\left(0, g_{o}^{t+1}, 0\right)\right)
$$

and

$$
L B_{t+1}=D^{t+1}\left(x^{t+1}, y^{t+1}, b^{t+1} ;\left(0,0, g_{B}^{t+1}\right)\right)-D^{t+1}\left(x^{t+1}, y^{t+1}, b^{t} ;\left(0,0, g_{B}^{t}\right)\right.
$$

From Equations (6) to (9) we can derive the total factor pollution-adjusted productivity change as an arithmetic mean of each period LHM quantity indicator. Thus, we have the following:

$$
\begin{gathered}
L H M_{t, t+1}=\frac{1}{2}\left(L H M_{t}+L H M_{t+1}\right) \\
L H M_{t, t+1}=\frac{1}{2}(L G-L B)
\end{gathered}
$$

where $L G=\frac{1}{2}\left(L G_{t}+L G_{t+1}\right)$ and $L B=\frac{1}{2}\left(L B_{t}+L B_{t+1}\right) . L G$ is the good-output TFP change, while $L B$ is the bad-output TFP change from $t$ to $t+1$. LHM Values greater than zero express productivity gains, while values below zero reflect productivity losses.

\section{Use of data envelopment analysis}

All the previous quantity indicator indicators can be estimated using DEA. For simplicity and paper length issues, we will only present two of the eight models that need to be solved to compute TFP in Equation (10). The good-output inefficiency in period $t$ given the other variable in the same period is presented in Equation (11).

$$
\begin{gathered}
D^{t}\left(x^{t}, y^{t}, b^{t} ;\left(0, g_{0}^{t}, 0\right)\right)=\max _{\beta, \lambda, \mu} \beta_{0}^{t} \\
\text { s.t. } \sum_{n=1}^{N} \lambda_{n}^{t} x_{k n}^{t} \leq x_{k 0}^{t} ; \sum_{n=1}^{N} \lambda_{n}^{t} y_{q n}^{t} \geq y_{q 0}^{t}+\beta_{0}^{t} g_{q o}^{t} ; \sum_{n=1}^{N} \lambda_{n}^{t}=1 \\
\sum_{n=1}^{N} \mu_{n}^{t} x_{k_{2} n}^{t} \geq x_{k_{2} 0}^{t} ; \sum_{n=1}^{N} \mu_{n}^{t} b_{r n}^{t} \leq b_{r 0}^{t} ; \sum_{n=1}^{N} \mu_{n}^{t}=1
\end{gathered}
$$

Similarly, the good output inefficiency in period $t+1$ using as reference inputs and bad outputs of period $t$ can be assessed using model in Equation (12).

$$
\begin{gathered}
D^{t}\left(x^{t}, y^{t+1}, b^{t} ;\left(0, g_{O}^{t+1}, 0\right)\right)=\max _{\beta, \lambda, \mu} \beta_{0}^{t} \\
\text { s.t. } \sum_{n=1}^{N} \lambda_{n}^{t} x_{k n}^{t} \leq x_{k 0}^{t} ; \sum_{n=1}^{N} \lambda_{n}^{t} y_{q n}^{t} \geq y_{q 0}^{t+1}+\beta_{0}^{t} g_{q o}^{t+1} ; \sum_{n=1}^{N} \lambda_{n}^{t}=1
\end{gathered}
$$




$$
\sum_{n=1}^{N} \mu_{n}^{t} x_{k_{2} n}^{t} \geq x_{k_{2} 0}^{t} ; \sum_{n=1}^{N} \mu_{n}^{t} b_{r n}^{t} \leq b_{r 0}^{t} ; \sum_{n=1}^{N} \mu_{n}^{t}=1
$$

As discussed earlier, some of the recent studies in the literature have also considered the internal structure of these companies by focusing on different stages of their production system. Although in this paper a single-stage by-production model is presented for the sake of simplicity and consistency with the previous by-production models, our model can easily be extended to network and dynamic analyses as conducted in the previous studies. All the previous analyses of airline productivity change (such as Barros \& Couto, 2013; Cui and Li, 2015; Yang \& Wang, 2016; Lee et al., 2015; 2016) have also employed a single-stage analysis but with different views of the production system. This study focuses on the operation stage or the flight business only, which is a crucial stage of the production network system and can directly be affected by the inclusion of $\mathrm{CO}_{2}$ emissions. Hence, we avoid airline behavioral adjustments (marketing functions) such as cost minimization or profit maximisation (Barros, 2008). As underlined in Mallikarjun (2015), the operation stage reflects the 'supply capacity' of an airline, as measured by available seat miles (ASM), available seat kilometer (ASK) or TKA in several studies, and corresponds to our primal quantity of technical production whereas other production stages, often measured by factors such as revenue passenger miles and operating revenues, represent the 'service demand' and 'revenue generation' of airlines (Mallikarjun, 2015). The latter stages in fact reflect the airline strategy to maximize revenues and profits by operating with some 'supply capacity' - an economic behavior rather than the technology of generating ASM, ASK or TKA which is the focus of this paper. In addition, given the sensitivity of non-parametric measures such as DEA to sample size and the number of variables, the discrimination power between different DMUs can be seriously affected (Daraio and Simar, 2007).

Our model discussed here does not account for a dynamic framework for different reasons. As described in the literature (Li et al., 2016b; Cui et al., 2016a; 2016b), the dynamic approach is based on the work of Färe and Grosskopf (1996) where some storable inputs and intermediate outputs used or produced in one period serve as inputs for the next period. In the airline literature, capital is treated as a storable input. This approach requires data describing investment levels and capital depreciation, which we do not have access to for this paper. ${ }^{7}$

\subsection{Data}

It is crucial for efficiency and productivity analyses to select the appropriate mix of inputs and outputs (Boussofiane et al., 1991; Dyson et al., 2001). Airlines face different prices on their inputs; for example, Asian countries have comparatively lower labour costs, Middle Eastern airlines likely benefit

\footnotetext{
${ }^{7}$ Depending on data availability, both network and dynamic approaches will be interesting leads for future research.
} 
from lower costs on fuel and tax rates vary across jurisdictions. These different prices could produce different input units (Greer, 2009). To overcome these differences and ensure comparability, only physical inputs and outputs were considered for this study. RDC Aviation provided all data, which were cross-referenced with annual reports and other publicly available data to ensure accuracy. ${ }^{8}$ The research period covers the years 2007 to 2013 which allows comparison with other recent similar studies and also avoids biases from including commercial flights using biofuels from 2014.

Cui and Li (2015 ; 2016), Li et al. (2016a) and Cui et al. (2016c) considered the period from 2008 to 2012 and Cui et al. (2016b) and Xu and Cui (2017) used the years 2008 to 2014 as reference period to evaluate performance of major international airlines from different aspects. There is a consensus among all these studies that our selected period can be seen as appropriate. Cui et al. (2016b, p.989) states "since the EU declared in 2008 that aviation will be included in the EU ETS in 2012, the years after 2008 can be considered a buffer period for global airlines. Although the policy is suspended for non-EU airlines, the EU firmly believes that the act can decelerate airline emissions and will continue to push it in future." Li et al. (2016a), Cui et al. (2016c), Cui and Li (2016) also argue that it is meaningful to study the efficiencies of major international airlines during period 2008-2012 which is included in our selected period. In addition, as mentioned earlier, the first commercial flights fuelled by 50 per cent biofuels (such as Lufthansa) took place in 2014. This would place additional requirements on the model however the data on how much biofuel was used by each airline to estimate their $\mathrm{CO}_{2}$-e was not available. Therefore, the period 2007-2013 is considered in this study.

Thirty-three full-service carriers (FSCs) are considered in this study with eight European, one Russian, four North American, one Latin American, twelve Chinese or North Asian, three Asia-Pacific and four Middle Eastern carriers. We focused on the world's major FSCs (not low-cost carriers and so on) to ensure comparability of business models.

The selection of data is well grounded in the existing literature (for example, Barla \& Perelman, 1989; Charnes et al., 1996; Greer, 2006; Inglada et al., 2006; Arjomandi \& Seufert, 2014). We identified labour and capital as major inputs. As asserted by Coelli et al. (1999) and Greer (2008), labour is measured by the annual average of full-time equivalent, and can be divided into two categories: pilots and flight attendants, which directly relate to the core business of airlines. This paper focuses on the flight operations and we deliberately excluded auxiliary services using ground staff such as catering and maintenance as these can and are often outsourced. As such figures of staff other than FTE pilot and flight attendants are very likely to be distorted. This study follows the Coelli et al. (1999, p. 262) definition of capital, which is the "sum of the maximum take-off weights of all aircraft multiplied by the number of days the planes have been able to operate during a year (defined as the total number of

\footnotetext{
${ }^{8}$ RDC Aviation (www.rdcaviation.com) is one of the leading aviation advisory and data analysis providers.
} 
flying hours divided by average daily revenue hours)". This definition avoids performance biases due to maintenance or other external impacts, and was also employed because of the high degree of complementarity between fuel consumption and capital (this correlation is above 0.95 in our case) when the consistency of fuel consumption data is a concern (Barla and Perelman,1989; Coelli et al., 1999; Ray 2008). We have considered the same inputs (capital and labour) under both subtechnologies.

To reflect the outputs of airlines, we chose tonne-kilometres available (TKA) and CO2-e emissions. TKA is the measure of desirable output for this study, following the logic of Barla and Perelman (1989), Coelli et al. (1999), Inglada et al. (2006) and Arjomandi and Seufert (2014) that TKA is not a marketing but capacity indicator (Greer, 2009). As Greer (2009, p. 779) asserts "the conversion of an airline's produced inventory of ASMs into revenue passenger-miles is a marketing function, not part of the airline's production process." As such this study uses TKA defined as the number of tonnes available for the carriage of revenue load (passengers, freight and mail) on each flight multiplied by the flight distance which includes ASMs as well. RDC provides estimated $\mathrm{CO}_{2}$-e data based on specific airline-aircraft configurations and the served sector to translate the estimated fuel consumption into $\mathrm{CO}_{2}$-e based on the widely accepted IPCC factor. These modelled $\mathrm{CO}_{2}$-e data have specific benefits of $\mathrm{CO}_{2}$-e extracted from annual reports or other publicly available sources: there is consistency of data because they come from one, rather than multiple sources. This is in line with the standardisation of external factors, weather, pilots' decisions on the choice of route, or airport-related factors that could impact $\mathrm{CO}_{2}$-e emission. In this paper we assume that production technologies available to airlines are homogeneous and the differences in business environment lead to different choices in technology not to differences in the technologies available to them. Descriptive statistics for all the inputs and outputs and the list of selected airlines, ordered by the size of capital, are provided in Tables 2 and 3, respectively.

Table 2. Descriptive statistics of the inputs and outputs

\begin{tabular}{lllll}
\hline Variable & Mean & Std. Dev. & Minimum & Maximum \\
\hline $\begin{array}{l}\text { The inputs } \\
\text { Number of employees }\end{array}$ & 9.78 & & & \\
Capital & 8.55 & 6.79 & 1.66 & 32.9 \\
The outputs & 6.50 & 1.91 & 38.70 \\
TKA & 105.10 & 78.41 & & \\
$\mathrm{CO}_{2}-\mathrm{e}$ & 10.58 & 7.96 & 22.84 & 458.86 \\
\hline
\end{tabular}

Notes: Number of Employees is measured as full time equivalent staff (in thousands). Capital is the sum of the maximum take-off weights of all aircraft multiplied by the number of days the planes have been able to operate during a year (defined as the total number of flying hours divided by average daily revenue hours) and is divided by $10^{12}$. TKA is the number of tonnes available for the carriage of revenue load (passengers, freight and mail) on each flight multiplied by the flight distance and is divided by $10^{12}$. Estimated $\mathrm{CO}_{2}$-e represents the Carbon Dioxide equivalent (in millions of tonnes) emitted by each airline for their flight business. RDC employed the specified model to estimate $\mathrm{CO}_{2}$-e which is a conversion from fuel, based on the IPCC's conversion factor. 
Table 3. Selected airlines and regions

\begin{tabular}{|c|c|c|}
\hline Airline & Region & Region Abbreviation \\
\hline Delta Air Lines & US and Canada & USC \\
\hline American Airlines & US and Canada & USC \\
\hline United Airlines & US and Canada & USC \\
\hline Emirates & Middle East & ME \\
\hline Lufthansa & Europe and Russia & EURU \\
\hline British Airways & Europe and Russia & EURU \\
\hline Cathay Pacific Airways & China and North Asia & CHNA \\
\hline Air France & Europe and Russia & EURU \\
\hline Singapore Airlines & China and North Asia & CHNA \\
\hline Korean Air & China and North Asia & CHNA \\
\hline KLM Royal Dutch Airlines & Europe and Russia & EURU \\
\hline Air Canada & US and Canada & USC \\
\hline Air China & China and North Asia & CHNA \\
\hline Qantas & Asia Pacific & $\mathrm{AP}$ \\
\hline Thai Airways International & Asia Pacific & $\mathrm{AP}$ \\
\hline China Southern Airlines & China and North Asia & CHNA \\
\hline China Airlines & China and North Asia & CHNA \\
\hline China Eastern Airlines & China and North Asia & CHNA \\
\hline Japan Airlines International & China and North Asia & CHNA \\
\hline Iberia & Europe and Russia & EURU \\
\hline Turkish Airlines (THY) & Europe and Russia & EURU \\
\hline Eva Air & Asia Pacific & $\mathrm{AP}$ \\
\hline Virgin Atlantic Airways & Europe and Russia & EURU \\
\hline Asiana Airlines & China and North Asia & CHNA \\
\hline Etihad Airways & Middle East & $\mathrm{ME}$ \\
\hline All Nippon Airways & China and North Asia & CHNA \\
\hline Malaysia Airlines & China and North Asia & CHNA \\
\hline TAM Linhas Aereas & Latin America & LA \\
\hline Air India & China and North Asia & CHNA \\
\hline Saudi Arabian Airlines & Middle East & $\mathrm{ME}$ \\
\hline Qatar Airways & Middle East & $\mathrm{ME}$ \\
\hline Aeroflot-Russian Airlines & Europe and Russia & EURU \\
\hline Alitalia & Europe and Russia & EURU \\
\hline
\end{tabular}

\section{Empirical results}

For the empirical application, the directional vectors used are equivalent to the observed values of the different variables (Chung et al., 1997). For instance, $g_{q o}^{t}=y_{q 0}^{t}$. We start with the efficiency results and thereafter discuss productivity changes. Table 4 lists several measures related to the by-production pollution-adjusted inefficiency (By-production inefficiency), good-output inefficiency (G.O. inefficiency) and bad-output inefficiency (B.O. inefficiency) of the individual airlines. For the sake of saving space, the inefficiency estimates of only three individual years (2007, 2010 and 2013) for all airlines are presented in Table 4. The table also includes each airline's ranking based on its byproduction, good-output and bad-output inefficiencies. ${ }^{9}$

\footnotetext{
${ }^{9}$ The results of years 2008, 2009, 2011, and 2012 can be provided upon request.
} 
Based on the results listed in Table 4, interested readers can identify the best and worst individual performers in the sample: United Airlines is consistently found to be the most efficient airline because its by-production, good-output and bad-output inefficiencies all equal zero in all years. Emirates is also found to be a top performer, because it is ranked among the top five performers based on its byproduction inefficiency in all reported years. Air India was a 'fully' efficient airline in the period 2007 to 2010 as well, but lost this position to other airlines, such as Eva Air, Singapore Airlines, Alitalia and Emirates in 2011 to 2013. Delta Airlines, Qatar Airways and Korean Air also show considerable ranking improvements in terms of pollution-adjusted efficiency (by-production) in 2011 to 2013. In fact, Delta Airlines and Qatar Airways were among the worst performers in 2007 to 2010, but were among the top 10 performers in 2011 to 2013. All Nippon Airways and Air China consistently ranked among the five worst performers in 2007 to 2013.

Focusing on the regions, airlines from the Europe region, except Turkish Airlines, were found to be better ranked than the 10 least efficient airlines in the last five studied years (by not falling into this category in the period 2009 to 2013). Turkish Airlines is by far the most inefficient airlines of the region, and its by-production inefficiency is mainly attributable to its bad-output management. ${ }^{10}$ Alitalia, Lufthansa and Air France can be seen as the region's most efficient airlines. It is worth mentioning that Alitalia was ranked 27th in the first year of our analysis, but managed to become one of the fully efficient airlines between 2011 and 2013. Airlines in China and northern Asia were found to be at very different stages of by-production efficiency: Air India and Singapore Airlines were among the world's most efficient airlines and All Nippon and Air China are positioned in the opposite position. None of the Chinese airlines were found to be in the top 10 most technically efficient airlines. ${ }^{11}$ China Southern Airlines performed very well in terms of bad-output management; however, its very poor good output efficiency ranked it about 15 across different years. Some airlines' rankings, such as those of Japan Airlines and Asiana Airlines, substantially worsened over time. The AsiaPacific region includes three airlines: Eva Air, a Taiwanese airline which was found to be in the world's top three most efficient airlines in all years (except for 2009 in which it was ranked the ninth); Qantas, which is not as efficient as Eva Air in terms of pollution-adjusted efficiency, but still among the top third of the best performers; and Thai Airways, which in this study never ranked better than 21st during the studied period. This was mainly because of its poor performance on bad output controlling. In fact, this airline was constantly among the five globally most pollution-adjusted inefficient airlines.

\footnotetext{
${ }^{10}$ It should be mentioned that although Turkish Airlines is classified by ICAO as part of the Europe region, Turkey itself is neither part of the European Union nor a participant in the EU ETS, and hence does not need to consider an imposed price on $\mathrm{CO}_{2}$-e (ICAO, 2015).

${ }^{11}$ Note that China Airlines has its headquarters in Taiwan, and hence is not considered as a mainland China airline. China Airlines was in fact among the top ten best performers in 2007, 2011 and 2012.
} 
Table 4. By-production, good-output and bad-output efficiency scores, 2007, 2010, and 2013

\begin{tabular}{|c|c|c|c|c|c|c|c|c|c|c|c|c|c|c|c|c|c|c|c|}
\hline \multirow[b]{2}{*}{ Airlines } & \multirow[b]{2}{*}{ Region } & \multicolumn{6}{|l|}{2007} & \multicolumn{6}{|l|}{2010} & \multicolumn{6}{|l|}{2013} \\
\hline & & $\begin{array}{l}\text { By-prod. } \\
\text { ineff. }\end{array}$ & $\begin{array}{l}\text { G.O. } \\
\text { ineff. }\end{array}$ & $\begin{array}{l}\text { B.O. } \\
\text { ineff. }\end{array}$ & $\begin{array}{l}\text { By- } \\
\text { prod. } \\
\text { rank }\end{array}$ & $\begin{array}{l}\text { G.O. } \\
\text { rank }\end{array}$ & $\begin{array}{l}\text { B.O } \\
\text { rank }\end{array}$ & $\begin{array}{l}\text { By- } \\
\text { prod. } \\
\text { ineff. }\end{array}$ & $\begin{array}{l}\text { G.O. } \\
\text { ineff. }\end{array}$ & $\begin{array}{l}\text { B.O. } \\
\text { ineff. }\end{array}$ & $\begin{array}{l}\text { By- } \\
\text { prod. } \\
\text { rank }\end{array}$ & $\begin{array}{l}\text { G.O. } \\
\text { rank }\end{array}$ & $\begin{array}{l}\text { B.O } \\
\text { rank }\end{array}$ & $\begin{array}{l}\text { By- } \\
\text { prod. } \\
\text { ineff. }\end{array}$ & $\begin{array}{l}\text { G.O. } \\
\text { ineff. }\end{array}$ & $\begin{array}{l}\text { B.O. } \\
\text { ineff. }\end{array}$ & $\begin{array}{l}\text { By- } \\
\text { prod. } \\
\text { rank }\end{array}$ & $\begin{array}{l}\text { G.O. } \\
\text { rank }\end{array}$ & $\begin{array}{l}\text { B.O } \\
\text { rank }\end{array}$ \\
\hline Delta Air Lines & USC & 0.208 & 0.124 & 0.291 & 24 & 16 & 19 & 0.196 & 0.175 & 0.217 & 20 & 22 & 12 & 0.031 & 0.028 & 0.034 & 5 & 4 & 3 \\
\hline American Airlines & USC & 0.050 & 0.101 & 0.000 & 6 & 13 & 1 & 0.235 & 0.118 & 0.353 & 28 & 18 & 23 & 0.024 & 0.049 & 0.000 & 3 & 7 & 1 \\
\hline United Airlines & USC & 0.000 & 0.000 & 0.000 & 1 & 1 & 1 & 0.000 & 0.000 & 0.000 & 1 & 1 & 1 & 0.000 & 0.000 & 0.000 & 1 & 1 & 1 \\
\hline Emirates & ME & 0.046 & 0.006 & 0.086 & 5 & 3 & 4 & 0.084 & 0.000 & 0.169 & 5 & 1 & 9 & 0.000 & 0.000 & 0.000 & 1 & 1 & 1 \\
\hline Lufthansa & EURU & 0.093 & 0.061 & 0.124 & 10 & 11 & 7 & 0.118 & 0.066 & 0.170 & 10 & 14 & 10 & 0.025 & 0.050 & 0.000 & 4 & 8 & 1 \\
\hline British Airways & EURU & 0.196 & 0.000 & 0.393 & 21 & 1 & 26 & 0.146 & 0.016 & 0.276 & 15 & 2 & 18 & 0.158 & 0.034 & 0.282 & 18 & 5 & 22 \\
\hline Cathay Pacific Airways & CHNA & 0.101 & 0.034 & 0.169 & 11 & 6 & 9 & 0.148 & 0.038 & 0.258 & 16 & 6 & 16 & 0.088 & 0.066 & 0.111 & 8 & 13 & 7 \\
\hline Air France & EURU & 0.029 & 0.058 & 0.000 & 4 & 10 & 1 & 0.115 & 0.067 & 0.164 & 9 & 15 & 7 & 0.064 & 0.040 & 0.088 & 6 & 6 & 5 \\
\hline Singapore Airlines & CHNA & 0.088 & 0.000 & 0.176 & 9 & 1 & 10 & 0.069 & 0.000 & 0.139 & 4 & 1 & 5 & 0.013 & 0.003 & 0.023 & 2 & 2 & 2 \\
\hline Korean Air & CHNA & 0.251 & 0.061 & 0.441 & 30 & 12 & 27 & 0.216 & 0.055 & 0.378 & 26 & 9 & 29 & 0.141 & 0.059 & 0.223 & 15 & 10 & 18 \\
\hline KLM Royal Dutch Airlines & EURU & 0.107 & 0.027 & 0.188 & 12 & 4 & 12 & 0.141 & 0.032 & 0.250 & 13 & 3 & 15 & 0.120 & 0.061 & 0.179 & 13 & 12 & 14 \\
\hline Air Canada & USC & 0.213 & 0.139 & 0.286 & 25 & 17 & 17 & 0.216 & 0.118 & 0.313 & 25 & 19 & 20 & 0.226 & 0.149 & 0.304 & 27 & 17 & 23 \\
\hline Air China & CHNA & 0.238 & 0.146 & 0.331 & 29 & 18 & 23 & 0.241 & 0.153 & 0.329 & 29 & 20 & 21 & 0.221 & 0.179 & 0.263 & 26 & 19 & 20 \\
\hline Qantas & AP & 0.068 & 0.004 & 0.132 & 8 & 2 & 8 & 0.100 & 0.041 & 0.158 & 7 & 7 & 6 & 0.112 & 0.054 & 0.170 & 12 & 9 & 13 \\
\hline Thai Airways International & AP & 0.198 & 0.052 & 0.344 & 22 & 8 & 24 & 0.209 & 0.057 & 0.361 & 22 & 11 & 25 & 0.164 & 0.060 & 0.267 & 21 & 11 & 21 \\
\hline China Southern Airlines & CHNA & 0.140 & 0.281 & 0.000 & 16 & 24 & 1 & 0.143 & 0.286 & 0.000 & 14 & 25 & 1 & 0.133 & 0.265 & 0.000 & 14 & 27 & 1 \\
\hline China Airlines & CHNA & 0.065 & 0.033 & 0.097 & 7 & 5 & 5 & 0.136 & 0.045 & 0.226 & 11 & 8 & 14 & 0.107 & 0.143 & 0.071 & 11 & 16 & 4 \\
\hline China Eastern Airlines & CHNA & 0.157 & 0.261 & 0.053 & 18 & 23 & 3 & 0.192 & 0.294 & 0.090 & 18 & 26 & 3 & 0.216 & 0.293 & 0.140 & 25 & 28 & 9 \\
\hline Japan Airlines International & CHNA & 0.135 & 0.168 & 0.101 & 15 & 21 & 6 & 0.302 & 0.218 & 0.386 & 32 & 23 & 30 & 0.311 & 0.231 & 0.391 & 30 & 24 & 26 \\
\hline Iberia & EURU & 0.199 & 0.105 & 0.294 & 23 & 14 & 20 & 0.091 & 0.081 & 0.101 & 6 & 16 & 4 & 0.159 & 0.118 & 0.201 & 20 & 15 & 15 \\
\hline Turkish Airlines (THY) & EURU & 0.234 & 0.153 & 0.315 & 28 & 19 & 21 & 0.262 & 0.175 & 0.349 & 30 & 21 & 22 & 0.169 & 0.169 & 0.170 & 23 & 18 & 12 \\
\hline Eva Air & AP & 0.004 & 0.000 & 0.009 & 2 & 1 & 2 & 0.028 & 0.000 & 0.056 & 3 & 1 & 2 & 0.000 & 0.000 & 0.000 & 1 & 1 & 1 \\
\hline Virgin Atlantic Airways & EURU & 0.178 & 0.000 & 0.357 & 19 & 1 & 25 & 0.155 & 0.000 & 0.310 & 17 & 1 & 19 & 0.106 & 0.000 & 0.212 & 10 & 1 & 16 \\
\hline Asiana Airlines & CHNA & 0.124 & 0.000 & 0.247 & 14 & 1 & 15 & 0.136 & 0.057 & 0.215 & 12 & 10 & 11 & 0.167 & 0.187 & 0.148 & 22 & 20 & 10 \\
\hline Etihad Airways & ME & 0.000 & 0.000 & 0.000 & 1 & 1 & 1 & 0.198 & 0.035 & 0.361 & 21 & 4 & 24 & 0.158 & 0.099 & 0.217 & 19 & 14 & 17 \\
\hline All Nippon Airways & CHNA & 0.286 & 0.305 & 0.267 & 31 & 25 & 16 & 0.290 & 0.317 & 0.263 & 31 & 27 & 17 & 0.228 & 0.210 & 0.246 & 28 & 23 & 19 \\
\hline Malaysia Airlines & CHNA & 0.023 & 0.047 & 0.000 & 3 & 7 & 1 & 0.212 & 0.063 & 0.361 & 23 & 13 & 26 & 0.152 & 0.000 & 0.305 & 16 & 1 & 24 \\
\hline TAM Linhas Aereas & LA & 0.221 & 0.241 & 0.201 & 26 & 22 & 13 & 0.196 & 0.224 & 0.168 & 19 & 24 & 8 & 0.153 & 0.191 & 0.116 & 17 & 21 & 8 \\
\hline Air India & CHNA & 0.000 & 0.000 & 0.000 & 1 & 1 & 1 & 0.000 & 0.000 & 0.000 & 1 & 1 & 1 & 0.104 & 0.207 & 0.000 & 9 & 22 & 1 \\
\hline Saudi Arabian Airlines & ME & 0.151 & 0.119 & 0.182 & 17 & 15 & 11 & 0.233 & 0.098 & 0.368 & 27 & 17 & 28 & 0.194 & 0.241 & 0.148 & 24 & 25 & 11 \\
\hline Qatar Airways & ME & 0.188 & 0.054 & 0.322 & 20 & 9 & 22 & 0.213 & 0.059 & 0.367 & 24 & 12 & 27 & 0.064 & 0.023 & 0.105 & 7 & 3 & 6 \\
\hline Aeroflot-Russian Airlines & EURU & 0.118 & 0.000 & 0.236 & 13 & 1 & 14 & 0.109 & 0.000 & 0.217 & 8 & 1 & 13 & 0.295 & 0.255 & 0.335 & 29 & 26 & 25 \\
\hline Alitalia & EURU & 0.226 & 0.163 & 0.288 & 27 & 20 & 18 & 0.019 & 0.038 & 0.000 & 2 & 5 & 1 & 0.000 & 0.000 & 0.000 & 1 & 1 & 1 \\
\hline
\end{tabular}


With regard to the Middle-Eastern airlines, Emirates was by far the most efficient airline. Qatar managed to improve its rank from 24st in 2010 to seventh in 2012-2013. Saudi Arabian Airlines and Etihad Airways were mostly ranked in the second third. TAM Linhas Aereas from Latin America was also in a position similar to Saudi Arabian Airlines and Etihad Airways. In the US and Canada region, United Airlines and Air Canada were found to be respectively the region's best and the worst performers. Another highlight from this region was Delta Air Lines, which showed a remarkable improvement in the years 2011 to 2013, compared to the previous period of study; its pollutionadjusted efficiency rank changed from 24th in 2007 to about fourth in the years 2011 to 2013.

Based on these pollution-adjusted measures, the findings of Table 4 reveal that: 1) United Airlines was the most efficient airline; 2) All Nippon Airways and Air China ${ }^{12}$ were across the years among the least efficient airlines; 3) no European airline (from the EU) was found to be among the 10 least efficient airlines ${ }^{13}$ after 2009; 4) no Chinese airline was found to be among the world's most efficient airlines; 5) airlines from almost all regions were found to be among the top 10 best performers.

The results on the LHM TFP (pollution-adjusted productivity) change, considering both good and bad outputs, can now give us a more in-depth understanding of airline performance. Any airline with high values of LG and LB (see Tables 5 and 6) can be seen as a good performer in managing both goodand bad-output productivities. However, as can be seen in Tables 5 and 6, there are not many airlines with positive LGs and LBs (positive productivity change), and there are many airlines that performed well based on one productivity component (LG or LB), but not on the other. Let us consider the period 2007 to 2008 to describe this better. Based on Table 5, Air India, with the highest LB but a negative LG, had the highest LHM TFP (pollution-adjusted productivity) change, and hence is ranked first in the list. In the same way, but with highest levels of LG, Qatar and TAM Linhas Aereas managed to be the second and third, respectively, in terms of the LHM TFP change in 2007 to 2008. Of special note is Etihad Airways, which had the largest positive change of LG (0.279); but because its LB was by far the poorest in comparison with others (-0.322), its LHM TFP change is ranked 29th. Eva Air and Malaysia Airlines were found to show the least productive changes in the period 2007 to 2008 (based on their LHM TFP values), because both their LGs and LBs were highly negative and largely lower than their rivals'. On the other hand, the LG and LB values of Iberia and Delta Airlines in the period 2007-2008 were both positive, indicating they experienced progress in terms of maximising TKA (LG) and also in terms of solely environmental performance (LB). However, because these are not the largest values in comparison with those of other airlines, they are ranked, respectively, fourth and fifth among all airlines.

\footnotetext{
${ }^{12}$ Using a dynamic model and total revenue as desirable output, Cui et al. (2016b) also found similar results for Air China and stated that this airline should exert more effort in controlling its emission volume. They suggested the fleet upgrade as an important tool for this aim.

${ }^{13}$ This finding is also in line with those of network SBMs in Cui and $\mathrm{Li}$ (2016) and Li et al. (2016a) which also showed that the average efficiency of European airlines was higher that of non-European airlines.
} 
Table 5. By-production LHM TFP change and its components, 2007-2008, 2008-2009, and 2009-2010

\begin{tabular}{|c|c|c|c|c|c|c|c|c|c|c|c|c|c|c|c|c|c|c|c|}
\hline \multirow[b]{2}{*}{ Airlines } & \multirow[b]{2}{*}{ Region } & \multicolumn{6}{|c|}{$2007-2008$} & \multicolumn{6}{|c|}{ 2008-2009 } & \multicolumn{6}{|c|}{ 2009-2010 } \\
\hline & & LHM & LG & $-\mathbf{L B}$ & $\begin{array}{l}\text { LHM } \\
\text { rank }\end{array}$ & $\begin{array}{l}\text { LG } \\
\text { rank }\end{array}$ & $\begin{array}{l}\text { LB } \\
\text { rank }\end{array}$ & LHM & LG & -LB & $\begin{array}{l}\text { LHM } \\
\text { rank }\end{array}$ & $\begin{array}{l}\text { LG } \\
\text { rank }\end{array}$ & $\begin{array}{l}\text { LB } \\
\text { rank }\end{array}$ & LHM & LG & -LB & $\begin{array}{l}\text { LHM } \\
\text { rank }\end{array}$ & $\begin{array}{l}\text { LG } \\
\text { rank }\end{array}$ & $\begin{array}{l}\text { LB } \\
\text { rank }\end{array}$ \\
\hline Delta Air Lines & USC & 0.112 & 0.043 & 0.069 & 5 & 10 & 4 & -0.019 & -0.102 & 0.083 & 21 & 26 & 9 & -0.110 & -0.056 & -0.053 & 31 & 30 & 23 \\
\hline American Airlines & USC & -0.027 & -0.086 & 0.059 & 27 & 30 & 7 & -0.001 & -0.110 & 0.110 & 18 & 29 & 5 & 0.020 & 0.019 & 0.001 & 8 & 17 & 9 \\
\hline United Airlines & USC & 0.005 & -0.055 & 0.060 & 23 & 28 & 5 & 0.002 & -0.032 & 0.034 & 17 & 16 & 16 & 0.035 & 0.047 & -0.011 & 7 & 12 & 14 \\
\hline Emirates & ME & 0.009 & 0.099 & -0.090 & 22 & 6 & 31 & 0.012 & 0.076 & -0.064 & 16 & 6 & 29 & -0.089 & 0.079 & -0.168 & 29 & 8 & 32 \\
\hline Lufthansa & EURU & 0.014 & 0.031 & -0.018 & 19 & 16 & 21 & 0.090 & -0.013 & 0.104 & 7 & 13 & 8 & -0.002 & 0.020 & -0.022 & 20 & 16 & 17 \\
\hline British Airways & EURU & 0.047 & -0.032 & 0.078 & 8 & 24 & 3 & 0.063 & -0.045 & 0.108 & 10 & 17 & 6 & 0.003 & -0.014 & 0.017 & 17 & 22 & 4 \\
\hline Cathay Pacific Airways & CHNA & 0.060 & 0.108 & -0.048 & 6 & 5 & 25 & -0.053 & -0.053 & -0.001 & 27 & 19 & 20 & 0.011 & 0.032 & -0.021 & 12 & 15 & 16 \\
\hline Air France & EURU & 0.022 & 0.031 & -0.009 & 15 & 17 & 17 & 0.070 & -0.048 & 0.118 & 9 & 18 & 4 & -0.015 & -0.027 & 0.012 & 21 & 24 & 5 \\
\hline Singapore Airlines & CHNA & 0.053 & 0.078 & -0.025 & 7 & 7 & 23 & 0.046 & -0.104 & 0.150 & 14 & 27 & 2 & -0.042 & -0.028 & -0.014 & 25 & 25 & 15 \\
\hline Korean Air & CHNA & 0.040 & 0.040 & 0.000 & 10 & 14 & 11 & 0.077 & 0.056 & 0.021 & 8 & 8 & 17 & -0.051 & -0.053 & 0.002 & 27 & 29 & 8 \\
\hline KLM Royal Dutch Airlines & EURU & 0.029 & 0.042 & -0.013 & 13 & 11 & 19 & 0.014 & -0.063 & 0.077 & 15 & 21 & 10 & 0.039 & 0.051 & -0.011 & 5 & 10 & 13 \\
\hline Air Canada & USC & 0.039 & 0.042 & -0.003 & 11 & 12 & 13 & 0.048 & 0.004 & 0.044 & 13 & 12 & 13 & 0.047 & 0.083 & -0.036 & 4 & 7 & 21 \\
\hline Air China & CHNA & 0.018 & 0.030 & -0.012 & 18 & 19 & 18 & -0.044 & 0.014 & -0.058 & 24 & 10 & 28 & 0.037 & 0.098 & -0.061 & 6 & 5 & 24 \\
\hline Qantas & AP & -0.019 & -0.015 & -0.004 & 25 & 22 & 14 & -0.024 & -0.068 & 0.044 & 22 & 23 & 14 & 0.009 & -0.001 & 0.009 & 14 & 19 & 6 \\
\hline Thai Airways International & $\mathrm{AP}$ & -0.043 & -0.037 & -0.006 & 28 & 25 & 16 & -0.047 & -0.112 & 0.065 & 25 & 30 & 11 & 0.017 & 0.039 & -0.022 & 10 & 14 & 18 \\
\hline China Southern Airlines & CHNA & 0.020 & 0.005 & 0.015 & 16 & 21 & 10 & 0.102 & 0.168 & -0.067 & 4 & 2 & 30 & 0.051 & 0.166 & -0.116 & 3 & 2 & 31 \\
\hline China Airlines & CHNA & -0.063 & -0.099 & 0.037 & 31 & 32 & 9 & -0.087 & 0.010 & -0.097 & 30 & 11 & 32 & 0.004 & -0.033 & 0.037 & 16 & 26 & 3 \\
\hline China Eastern Airlines & CHNA & 0.002 & 0.018 & -0.016 & 24 & 20 & 20 & -0.002 & 0.085 & -0.087 & 19 & 5 & 31 & -0.017 & 0.078 & -0.095 & 22 & 9 & 28 \\
\hline Japan Airlines International & CHNA & -0.055 & -0.053 & -0.002 & 30 & 27 & 12 & -0.141 & -0.108 & -0.033 & 31 & 28 & 24 & -0.174 & -0.297 & 0.123 & 32 & 33 & 1 \\
\hline Iberia & EURU & 0.122 & 0.062 & 0.060 & 4 & 9 & 6 & 0.117 & -0.031 & 0.148 & 3 & 15 & 3 & -0.018 & -0.012 & -0.005 & 23 & 21 & 10 \\
\hline Turkish Airlines (THY) & EURU & 0.032 & 0.109 & -0.077 & 12 & 4 & 29 & 0.146 & 0.180 & -0.033 & 1 & 1 & 25 & 0.010 & 0.098 & -0.087 & 13 & 6 & 27 \\
\hline Eva Air & $\mathrm{AP}$ & -0.094 & -0.061 & -0.033 & 32 & 29 & 24 & -0.055 & -0.016 & -0.040 & 28 & 14 & 26 & 0.002 & -0.007 & 0.009 & 18 & 20 & 7 \\
\hline Virgin Atlantic Airways & EURU & 0.011 & 0.030 & -0.020 & 20 & 18 & 22 & -0.017 & -0.066 & 0.049 & 20 & 22 & 12 & 0.002 & -0.045 & 0.047 & 19 & 28 & 2 \\
\hline Asiana Airlines & CHNA & 0.009 & 0.066 & -0.056 & 21 & 8 & 27 & 0.145 & 0.039 & 0.105 & 2 & 9 & 7 & 0.016 & 0.049 & -0.033 & 11 & 11 & 20 \\
\hline Etihad Airways & ME & -0.043 & 0.280 & -0.323 & 29 & 1 & 33 & 0.051 & 0.149 & -0.098 & 12 & 3 & 33 & 0.052 & 0.150 & -0.098 & 1 & 3 & 29 \\
\hline All Nippon Airways & CHNA & 0.028 & 0.034 & -0.005 & 14 & 15 & 15 & -0.048 & -0.058 & 0.010 & 26 & 20 & 18 & -0.041 & -0.035 & -0.006 & 24 & 27 & 11 \\
\hline Malaysia Airlines & CHNA & -0.213 & -0.052 & -0.161 & 33 & 26 & 32 & -0.177 & -0.155 & -0.022 & 33 & 33 & 23 & -0.065 & -0.059 & -0.007 & 28 & 31 & 12 \\
\hline TAM Linhas Aereas & LA & 0.137 & 0.190 & -0.053 & 2 & 3 & 26 & 0.092 & 0.137 & -0.045 & 5 & 4 & 27 & 0.017 & 0.133 & -0.115 & 9 & 4 & 30 \\
\hline Air India & CHNA & 0.146 & -0.094 & 0.240 & 1 & 31 & 1 & -0.148 & -0.137 & -0.011 & 32 & 31 & 21 & 0.008 & 0.040 & -0.032 & 15 & 13 & 19 \\
\hline Saudi Arabian Airlines & $\mathrm{ME}$ & 0.019 & -0.031 & 0.050 & 17 & 23 & 8 & -0.078 & -0.081 & 0.003 & 29 & 24 & 19 & -0.044 & 0.006 & -0.051 & 26 & 18 & 22 \\
\hline Qatar Airways & ME & 0.123 & 0.210 & -0.087 & 3 & 2 & 30 & 0.058 & 0.075 & -0.017 & 11 & 7 & 22 & 0.051 & 0.233 & -0.182 & 2 & 1 & 33 \\
\hline Aeroflot-Russian Airlines & EURU & -0.025 & 0.040 & -0.065 & 26 & 13 & 28 & -0.043 & -0.083 & 0.040 & 23 & 25 & 15 & -0.215 & -0.131 & -0.083 & 33 & 32 & 26 \\
\hline Alitalia & EURU & 0.043 & -0.161 & 0.204 & 9 & 33 & 2 & 0.092 & -0.150 & 0.242 & 6 & 32 & 1 & -0.089 & -0.018 & -0.071 & 30 & 23 & 25 \\
\hline
\end{tabular}

Note: LB values are multiplied by -1 for the sake of interpretation convenience. '-LB' instead of 'LB' is provided in the table. 
Table 6. By-production LHM TFP change and its components, 2010-2011, 2011-2012, and 2012-2013

\begin{tabular}{|c|c|c|c|c|c|c|c|c|c|c|c|c|c|c|c|c|c|c|c|}
\hline \multirow[b]{2}{*}{ Airlines } & \multirow[b]{2}{*}{ Region } & \multicolumn{6}{|c|}{ 2010-2011 } & \multicolumn{6}{|c|}{ 2011-2012 } & \multicolumn{6}{|c|}{$2012-2013$} \\
\hline & & LHM & LG & $-\mathbf{L B}$ & $\begin{array}{l}\text { LHM } \\
\text { rank }\end{array}$ & $\begin{array}{l}\text { LG } \\
\text { rank }\end{array}$ & $\begin{array}{l}\text { LB } \\
\text { rank }\end{array}$ & LHM & LG & -LB & $\begin{array}{l}\text { LHM } \\
\text { rank }\end{array}$ & $\begin{array}{l}\text { LG } \\
\text { rank }\end{array}$ & $\begin{array}{l}\text { LB } \\
\text { rank }\end{array}$ & LHM & LG & -LB & $\begin{array}{l}\text { LHM } \\
\text { rank }\end{array}$ & $\begin{array}{l}\text { LG } \\
\text { rank }\end{array}$ & $\begin{array}{l}\text { LB } \\
\text { rank }\end{array}$ \\
\hline Delta Air Lines & USC & 0.245 & 0.625 & -0.380 & 4 & 1 & 31 & 0.004 & -0.038 & 0.042 & 18 & 25 & 5 & -0.024 & 0.005 & -0.029 & 27 & 24 & 18 \\
\hline American Airlines & USC & 0.000 & 0.005 & -0.005 & 23 & 31 & 2 & -0.025 & -0.039 & 0.014 & 26 & 26 & 13 & 0.134 & 0.563 & -0.428 & 2 & 1 & 33 \\
\hline United Airlines & USC & -0.160 & 0.379 & -0.539 & 32 & 4 & 33 & -0.103 & -0.129 & 0.026 & 32 & 31 & 10 & -0.098 & -0.115 & 0.017 & 32 & 32 & 9 \\
\hline Emirates & ME & 0.090 & 0.216 & -0.126 & 8 & 8 & 28 & 0.007 & 0.154 & -0.147 & 16 & 4 & 32 & 0.069 & 0.138 & -0.069 & 7 & 7 & 23 \\
\hline Lufthansa & EURU & 0.014 & 0.096 & -0.082 & 19 & 15 & 24 & 0.013 & -0.021 & 0.034 & 14 & 22 & 8 & 0.001 & -0.019 & 0.019 & 21 & 26 & 8 \\
\hline British Airways & EURU & -0.018 & 0.029 & -0.047 & 28 & 29 & 15 & -0.019 & 0.006 & -0.026 & 25 & 19 & 19 & -0.005 & 0.016 & -0.022 & 23 & 19 & 17 \\
\hline Cathay Pacific Airways & CHNA & 0.018 & 0.095 & -0.077 & 18 & 16 & 21 & 0.029 & 0.088 & -0.060 & 10 & 11 & 24 & 0.078 & 0.005 & 0.073 & 6 & 23 & 2 \\
\hline Air France & EURU & 0.045 & 0.086 & -0.041 & 12 & 17 & 11 & 0.017 & 0.001 & 0.016 & 13 & 21 & 12 & 0.044 & 0.009 & 0.036 & 9 & 22 & 6 \\
\hline Singapore Airlines & CHNA & 0.070 & 0.139 & -0.069 & 10 & 11 & 19 & 0.000 & 0.056 & -0.055 & 20 & 12 & 22 & -0.009 & 0.009 & -0.018 & 25 & 21 & 15 \\
\hline Korean Air & CHNA & 0.141 & 0.186 & -0.045 & 7 & 9 & 12 & 0.023 & 0.053 & -0.030 & 12 & 14 & 20 & 0.019 & 0.017 & 0.002 & 15 & 18 & 11 \\
\hline KLM Royal Dutch Airlines & EURU & -0.014 & 0.039 & -0.053 & 27 & 25 & 17 & -0.025 & -0.024 & -0.001 & 27 & 23 & 14 & 0.008 & 0.003 & 0.005 & 19 & 25 & 10 \\
\hline Air Canada & USC & 0.012 & 0.035 & -0.023 & 20 & 27 & 4 & -0.001 & 0.003 & -0.004 & 21 & 20 & 15 & -0.035 & -0.023 & -0.012 & 29 & 27 & 14 \\
\hline Air China & CHNA & 0.036 & 0.065 & -0.029 & 13 & 20 & 6 & 0.062 & 0.045 & 0.018 & 3 & 16 & 11 & -0.036 & 0.059 & -0.095 & 30 & 15 & 26 \\
\hline Qantas & AP & 0.036 & 0.061 & -0.025 & 14 & 22 & 5 & -0.047 & -0.078 & 0.031 & 29 & 27 & 9 & -0.050 & -0.086 & 0.036 & 31 & 31 & 5 \\
\hline Thai Airways International & $\mathrm{AP}$ & 0.033 & 0.051 & -0.019 & 16 & 24 & 3 & 0.012 & -0.027 & 0.039 & 15 & 24 & 6 & 0.025 & 0.088 & -0.063 & 14 & 11 & 22 \\
\hline China Southern Airlines & CHNA & -0.013 & 0.069 & -0.082 & 26 & 18 & 23 & 0.056 & 0.140 & -0.084 & 4 & 5 & 26 & 0.014 & 0.123 & -0.110 & 17 & 9 & 27 \\
\hline China Airlines & CHNA & 0.004 & 0.037 & -0.034 & 22 & 26 & 9 & 0.003 & 0.049 & -0.046 & 19 & 15 & 21 & 0.034 & 0.043 & -0.009 & 12 & 17 & 13 \\
\hline China Eastern Airlines & CHNA & 0.035 & 0.113 & -0.079 & 15 & 14 & 22 & 0.045 & 0.139 & -0.093 & 6 & 6 & 28 & 0.083 & 0.196 & -0.113 & 5 & 4 & 28 \\
\hline Japan Airlines International & CHNA & -0.063 & -0.076 & 0.014 & 31 & 33 & 1 & 0.045 & 0.053 & -0.008 & 7 & 13 & 17 & 0.044 & 0.084 & -0.040 & 10 & 13 & 21 \\
\hline Iberia & EURU & 0.075 & 0.120 & -0.046 & 9 & 13 & 13 & -0.013 & -0.093 & 0.080 & 23 & 28 & 2 & -0.246 & -0.382 & 0.136 & 33 & 33 & 1 \\
\hline Turkish Airlines (THY) & EURU & 0.397 & 0.563 & -0.166 & 2 & 3 & 30 & 0.034 & 0.168 & -0.134 & 9 & 2 & 31 & 0.095 & 0.245 & -0.150 & 3 & 2 & 31 \\
\hline Eva Air & $\mathrm{AP}$ & -0.002 & 0.033 & -0.035 & 24 & 28 & 10 & -0.037 & 0.024 & -0.061 & 28 & 17 & 25 & 0.016 & 0.045 & -0.029 & 16 & 16 & 19 \\
\hline Virgin Atlantic Airways & EURU & -0.009 & 0.024 & -0.033 & 25 & 30 & 8 & -0.002 & 0.009 & -0.010 & 22 & 18 & 18 & -0.010 & -0.043 & 0.033 & 26 & 28 & 7 \\
\hline Asiana Airlines & CHNA & 0.007 & 0.059 & -0.051 & 21 & 23 & 16 & 0.040 & 0.099 & -0.059 & 8 & 10 & 23 & 0.134 & 0.171 & -0.036 & 1 & 6 & 20 \\
\hline Etihad Airways & ME & 0.060 & 0.131 & -0.070 & 11 & 12 & 20 & 0.006 & 0.114 & -0.107 & 17 & 9 & 29 & 0.052 & 0.172 & -0.121 & 8 & 5 & 29 \\
\hline All Nippon Airways & CHNA & 0.169 & 0.237 & -0.068 & 6 & 7 & 18 & 0.110 & 0.117 & -0.007 & 2 & 7 & 16 & 0.034 & 0.111 & -0.077 & 13 & 10 & 24 \\
\hline Malaysia Airlines & CHNA & -0.035 & -0.004 & -0.030 & 29 & 32 & 7 & -0.015 & -0.120 & 0.105 & 24 & 30 & 1 & 0.002 & 0.127 & -0.124 & 20 & 8 & 30 \\
\hline TAM Linhas Aereas & LA & -0.040 & 0.061 & -0.101 & 30 & 21 & 27 & 0.117 & 0.529 & -0.412 & 1 & 1 & 33 & -0.006 & -0.078 & 0.071 & 24 & 30 & 3 \\
\hline Air India & CHNA & -0.249 & 0.145 & -0.394 & 33 & 10 & 32 & -0.048 & -0.096 & 0.049 & 30 & 29 & 4 & 0.040 & 0.059 & -0.020 & 11 & 14 & 16 \\
\hline Saudi Arabian Airlines & $\mathrm{ME}$ & 0.241 & 0.328 & -0.088 & 5 & 6 & 25 & -0.070 & -0.136 & 0.066 & 31 & 32 & 3 & 0.009 & 0.015 & -0.005 & 18 & 20 & 12 \\
\hline Qatar Airways & ME & 0.269 & 0.358 & -0.089 & 3 & 5 & 26 & 0.028 & 0.117 & -0.088 & 11 & 8 & 27 & -0.004 & 0.088 & -0.092 & 22 & 12 & 25 \\
\hline Aeroflot-Russian Airlines & EURU & 0.425 & 0.569 & -0.144 & 1 & 2 & 29 & 0.050 & 0.162 & -0.112 & 5 & 3 & 30 & 0.087 & 0.241 & -0.154 & 4 & 3 & 32 \\
\hline Alitalia & EURU & 0.022 & 0.069 & -0.047 & 17 & 19 & 14 & -0.143 & -0.180 & 0.037 & 33 & 33 & 7 & -0.030 & -0.074 & 0.043 & 28 & 29 & 4 \\
\hline
\end{tabular}

Note: LB values are multiplied by -1 for the sake of interpretation convenience. '-LB' instead of 'LB' is provided in the table. 
Focusing on the regions, in the Middle East, one may not see any obvious highlights by looking at the LHM TFP results; however, when the LG and LB changes are compared, the findings are very interesting (Tables 5 and 6). Emirates, Etihad Airways and Qatar Airways have constantly shown very high and positive LG changes in any of the periods, but when it comes to the LB changes, we see the opposite: all the values are highly negative with no exceptions in all periods. Therefore, they are ranked among the most productive airlines in terms of good-output productivity change, but positioned as the worst performers when it comes to changes in environmental productivity. This may indicate that the Middle Eastern airlines are focusing on marketing strategies more than fuel/ $\mathrm{CO}_{2}$ reduction. Chinese airlines were found to be somewhat similar to their Middle Eastern rivals. Air China and China Southern Airlines show high and positive LGs, but negative LBs. China Eastern improved its LHM TFP substantially over time. But this was again due to its LG improvements over time only. Its LB values were always negative and even worsened over time. Hence, a similar conclusion as for the Middle Eastern airlines may also be drawn for Chinese airlines as well as airlines such as AeroflotRussian Airlines (from the Russian region), All Nippon Airways, Asiana, China Airlines, Cathay Pacific Airways and Japan Airlines (from the north Asia region), TAM Linhas Aereas (from the Latin America region) and Turkish Airlines (from the European region), which also show very similar LG and LB changes in most of the periods. On the other hand, European airlines show significant improvements in their LB values, and thus in 2012-2013, all the EU airlines, except British Airways, showed positive LBs.

With regard to LG changes, European airlines are ranked in the middle third among all airlines, but when it comes to exclusive environmental productivity change, they performed relatively better. See, for example, the performance of Iberia, Air France, Alitalia and Lufthansa in different years. With regard to the North American airlines, the good- and bad-output TFP changes vary over time.

\section{Conclusions}

This paper analyses the pollution-adjusted efficiency and productivity of the world's major airlines using innovative and recent DEA by-production models covering the period 2007 to 2013. Unlike the traditional Hicks-Moorsteen total factor productivity index, our indicator includes undesirable outputs using a representation of polluting technologies (by-production). The flexibility offered by this multitechnology approach allows us to decompose the global TFP into good- and bad-output components, thus providing insights into pollution-adjusted productivity change sources. As recently identified in some of the aforementioned literature (Dakpo et al., 2016; Førsund, 2017), other models considering pollution as an input under the strong disposability assumption or as an undesirable output under the WDA fail both to represent the production process that generates pollution in terms of trade-offs and to satisfy thermodynamic laws. 
Based on the findings of this study, one may argue that ETSs can trigger an environmental awareness or (cost) pressure for airlines to take their carbon footprint more seriously into account in their business strategy. That is, airlines facing either inclusion or the direct cost of an ETS are more likely to consider their environmental efficiency. Also, our findings suggest that, for our period of research, Middle Eastern airlines were less concerned about their environmental performance, most likely because fuel was cheaper and they were less concerned about the cost impact of higher fuel consumption. In contrast, European Airlines (those which are part of the EU ETS) show high pollution-adjusted efficiency and improvements in LHM productivity, which can be due to cost pressures and a potential higher environmental awareness of their passengers. Turkish Airlines, which has not been part of the EU ETS, might be a good counter example to show that a lack of incentive directly leads to a lack of LB improvements. Similarly, it can be argued that since Japan's regional and national ETSs did not include aviation emissions and they did not pose a threat to their financial bottom line, resulting in the airlines behaving as though they do not need to comply with an ETS at all.

Future research could take other aspects, such as marketing, costs and profit, into account to provide a more detailed picture of airline business operations. For this aim, the network and dynamic byproduction approaches can provide interesting insights into the performance of the airlines. While we considered the uniformity of $\mathrm{CO}_{2}$-e data by RDC compelling, more comprehensive actual data could provide additional insights into the eco-efficiency and eco-effectiveness changes of airlines' ground and other operational activities.

As fuel costs are not directly included in our model, regional differences in fuel costs for airlines do not have a direct bearing on our results. Future studies could also investigate the relative significance of regional differences in fuel costs compared with the impact of the EU ETS by considering altered sets of inputs and outputs or utilising a different type of undesirable output. This could be a valuable investigation of airlines' performance, as an ETS or any other factor that results in higher fuel prices (or even higher price volatility) may trigger airlines to improve fuel efficiency in order to minimise operating costs, thereby reducing exhaust emissions. Future studies could also extend the study period beyond 2013 and include the effect of biofuels on airline technical and environmental efficiency and productivity.

\section{Acknowledgment}

We would like to thank the Editor, the Associate Editor and the anonymous reviewers for their insightful comments, which have led to substantial improvements in the paper. We also thank Professor Karlheinz Kautz (former Associate Dean (Research), Faculty of Business, University of Wollongong) for supporting this study. In addition, we would like to thank Dr Marion McCutcheon for her excellent assistance in the preparation of this paper. Any remaining errors are the authors'. 


\section{References}

Alam, I. M. S., \& Sickles, R. C. (1998). The relationship between stock market returns and technical efficiency innovations: Evidence from the US airline industry. Journal of Productivity Analysis, 9(1), 35-51. doi: 10.1023/A:1018368313411

Alam, I. M. S., \& Sickles, R. C. (2000). Time series analysis of deregulatory dynamics and technical efficiency: The case of the US airline industry. International Economic Review, 41(1), 203218. doi: http://www.jstor.org/stable/2648829

Arjomandi, A. (2011). Efficiency and productivity of Iran's financial institutions, Thesis 3386, University of Wollongong Thesis Collection.

Arjomandi, A., Salleh, M. I., \& Mohammadzadeh, A. (2015). Measuring productivity change in higher education: an application of Hicks-Moorsteen total factor productivity index to Malaysian public universities. Journal of the Asia Pacific Economy, 20(4), 630-643. doi: http://dx.doi.org/10.1080/13547860.2015.1045323

Arjomandi, A., \& Seufert, J. H. (2014). An evaluation of the world's major airlines technical and environmental performance. Economic Modelling, 41, 133-144. doi: http://dx.doi.org/10.1016/j.econmod.2014.05.002

Assaf, A. (2011). A fresh look at the productivity and efficiency changes of UK airlines. Applied Economics, 43(17): 2165-2175. doi: 10.1080/00036840903085071

Australian Government (2014). Repealing the Carbon Tax, retrieved 19 June 2015, from http://www.environment.gov.au/climate-change/repealing-carbon-tax

Baltagi, B. H., Griffin, J. M., \& Rich, D. P. (1995). Airline deregulation: The cost pieces of the puzzle. International Economic Review, 36(1), 245-259. doi: http://dx.doi.org/10.2307/2527435.

Barla, P., \& Perelman, S. (1989). Technical Efficiency in Airlines under Regulated and Deregulated Environments. Annals of Public and Cooperative Economics, 60(1), 103-124. doi: http://dx.doi.org/10.1111/j.1467-8292.1989.tb02011.x

Barros, C. P., \& Couto, E. (2013). Productivity analysis of European airlines, 2000-2011. Journal of Air Transport Management, 31, 11-13. doi: http://dx.doi.org/10.1016/j.jairtraman.2012.10.006

Barros, C. P., \& Peypoch, N. (2009). An evaluation of European airlines' operational performance. International Journal of Production Economics, 122(2), 525-533. doi: http://dx.doi.org/10.1016/j.ijpe.2009.04.016

Bauer, P.W. (1990). Decomposing TFP growth in the presence of cost inefficiency, nonconstant returns to scale, and technological progress. Journal of Productivity Analysis, 1(4), 287-299. doi: http://dx.doi.org/10.1007/BF00160047

Bhadra, D. (2009). Race to the bottom or swimming upstream: Performance analysis of US airlines. Journal of Air Transport Management, 15, 227-235. doi: http://dx.doi.org/10.1016/j.jairtraman.2008.09.014

Bjurek, H. (1996). The Malmquist Total Factor Productivity Index. The Scandinavian Journal of Economics, 98(2), 303-313. doi: http://dx.doi.org/10.2307/3440861

Boussofiane, A., Dyson, R. G., \& Thanassoulis, E. (1991). Applied data envelopment analysis. European Journal of Operational Research, 52(1), 1-15. doi: http://dx.doi.org/10.1016/03772217(91)90331-O

Briec, W., \& Kerstens, K. (2004). A Luenberger-Hicks-Moorsteen Productivity Indicator: Its Relation to the Hicks-Moorsteen Productivity Index and the Luenberger Productivity Indicator. Economic Theory, 23(4), 925-939. doi: http://dx.doi.org/10.1007/s00199-003-0403-2 
Bureau of Environment Tokyo Metropolitan Government (2012). Tokyo Cap-and-Trade Program for Large Facilities, retrieved 16 June 2015, from

https://www.kankyo.metro.tokyo.jp/en/climate/attachement/C\%26T\%202012.pdf

Capobianco, H. M. P., \& Fernandes, E. (2004). Capital structure in the world airline industry. Transportation Research Part A: Policy and Practice, 38(6), 421-434. doi: http://dx.doi.org/10.1016/j.tra.2004.03.002

Caves, D. W., Christensen, L. R., \& Tretheway, M. W. (1984). Economies of density versus economies of scale: Why trunk and local service airline costs differ. The RAND Journal of Economics, 15, 471-489. doi: http://www.jstor.org/stable/2555519

Caves, D. W., Christensen, L. R., \& Tretheway, M. W. (1981). US Trunk Air Lines, 1972-1997: A Multilateral Comparison of Total Factor Productivity, in Cowing, T. G., Stevenson, R. E. (ed.). Productivity Measurement in Regulated Industries, Academic Press, New York, 47-77.

Chambers, R. G., Serra, T., \& Oude Lansink, A. (2014). On the pricing of undesirable state-contingent outputs. European Review of Agricultural Economics, 41, 485-509. doi: http://dx.doi.org/10.1093/erae/jbu018

Chang, Y.T., Park, H.S., Jeong, J.B., \& Lee, J.W. (2014). Evaluating economic and environmental efficiency of global airlines: A SBM-DEA approach. Transportation Research Part D: Transport and Environment, 27, 46-50. doi: http://dx.doi.org/10.1016/j.trd.2013.12.013

Charnes, A., Cooper, W. W., \& Rhodes, E. (1978). Measuring the efficiency of decision making units. European Journal of Operational Research, 2(6), 429-444.

Charnes, A., Gallegos, A., \& Li, H. (1996). Robustly efficient parametric frontiers via Multiplicative DEA for domestic and international operations of the Latin American airline industry. European Journal of Operational Research, 88(3), 525-536. doi: http://dx.doi.org/10.1016/0377-2217(94)00216-9

Chen, C.M. (2013a). A critique of non-parametric efficiency analysis in energy economics studies. Energy Economics, 38, 146-152. doi: http://dx.doi.org/10.1016/j.eneco.2013.03.009

Chen, C. M. (2013b). Evaluating eco-efficiency with data envelopment analysis: an analytical reexamination. Annals of Operations Research, 214(1), 49-71. doi: http://dx.doi.org/10.1007/s10479-013-1488-z

Chiou, Y. C., \& Chen, Y. H. (2006). Route-based performance evaluation of Taiwanese domestic airlines using data envelopment analysis. Transportation Research Part E: Logistics and Transportation Review, 42(2), 116-127. doi: http://dx.doi.org/10.1016/j.tre.2007.01.004

Cho, M. (2012). South Korea approves carbon trading scheme, retrieved 16 June 2015, from http://www.reuters.com/article/2012/05/02/us-carbon-korea-idUSBRE8410TN20120502

Chow, C.K.W. (2010). Measuring the productivity changes of Chinese airlines: The impact of the entries of non-state owned carriers. Journal of Air Transport Management, 16(6), 320-324. doi: http://dx.doi.org/10.1016/j.jairtraman.2010.04.001

Chung, Y. H., Färe, R., \& Grosskopf, S. (1997). Productivity and Undesirable Outputs: A Directional Distance Function Approach. Journal of Environmental Management, 51(3), 229-240. doi: http://dx.doi.org/10.1006/jema.1997.0146

Coelli, T., Grifell-Tatjé, E., \& Perelman, S. (2002). Capacity utilisation and profitability: A decomposition of short-run profit efficiency. International Journal of Production Economics, 79(3), 261-278. doi: http://dx.doi.org/10.1016/S0925-5273(02)00236-0

Coelli, T., Lauwers, L., \& Van Huylenbroeck, G. (2007). Environmental Efficiency Measurement and the Materials Balance Condition. Journal of Productivity Analysis, 28, 3-12. doi: 10.1007/s11123-007-0052-8 
Coelli, T., Perelman, S., \& Romano, E. (1999). Accounting for Environmental Influences in Stochastic Frontier Models: With Application to International Airlines. Journal of Productivity Analysis, 11(3), 251-273. doi: http://dx.doi.org/10.1023/a:1007794121363

Cornwell, C., Schmidt, P., \& Sickles, R. C. (1990). Production frontiers with cross-sectional and timeseries variation in efficiency levels. Journal of Economics, 46(1/2), 185-200. doi: http://dx.doi.org/10.1016/0304-4076(90)90054-W

Cui, Q., \& Li, Y. (2015). Evaluating energy efficiency for airlines: An application of VFB-DEA. Journal of Air Transport Management, 44-45, 34-41. doi: http://dx.doi.org/10.1016/j.jairtraman.2015.02.008

Cui, Q., \& Li, Y. (2016). Airline energy efficiency measures considering carbon abatement: A new strategic framework. Transportation Research Part D: Transport and Environment, 49, 246258. doi: 10.1016/j.trd.2016.10.003

Cui, Q., Li, Y., Yu, C. L., \& Wei, Y. M. (2016a). Evaluating energy efficiency for airlines: An application of virtual frontier dynamic slacks based measure. Energy, 113, 1231-1240. doi: http://dx.doi.org/10.1016/j.energy.2016.07.141

Cui, Q., Wei, Y. M., \& Li, Y. (2016b). Exploring the impacts of the EU ETS emission limits on airline performance via the Dynamic Environmental DEA approach. Applied Energy, 183, 984-994. doi: 10.1016/j.apenergy.2016.09.048

Cui, Q., Wei, Y. M., Yu, C. L., \& Li, Y. (2016c). Measuring the energy efficiency for airlines under the pressure of being included into the EU ETS. Journal of Advanced Transportation, doi: 10.1002/atr.1420

Dakpo, K. H., Jeanneaux, P., \& Latruffe, L. (2016). Modelling pollution-generating technologies in performance benchmarking: Recent developments, limits and future prospects in the nonparametric framework. European Journal of Operational Research, 250(2), 347-359. doi: http://dx.doi.org/10.1016/j.ejor.2015.07.024

Daraio, C., \& Simar, L. (2007). Advanced Robust and Nonparametric Methods in Efficiency Analysis: Methodology and Applications. Studies in Productivity and Efficiency. Springer. doi: 10.1007/978-0-387-35231-2

Diewert, W. E. (1992). Fisher ideal output, input, and productivity indexes revisited. Journal of Productivity Analysis, 3(3), 211-248. doi: 10.1007/BF00158354

Distexhe, V., \& Perelman, S. (1994). Technical efficiency and productivity growth in an era of deregulation: the case of airlines. Swiss Journal of Economics and Statistics, 130(4), 669-689. doi: http://www.sjes.ch/papers/1994-IV-4.pdf

Dyson, R. G., Allen, R., Camanho, A. S., Podinovski, V. V., Sarrico, C. S., \& Shale, E. A. (2001). Pitfalls and protocols in DEA. European Journal of Operational Research, 132(2), 245-259. doi: http://dx.doi.org/10.1016/S0377-2217(00)00149-1

Ehrlich, I., Gallais-Hamonno, G., Liu, Z., \& Lutter, R. (1994). Productivity growth and firm ownership: An analytical and empirical investigation. Journal of Political Economy, 102, 1006-1038. doi: http://dx.doi.org/10.1086/261962

EPA. (2015). EPA Takes First Steps to Address Greenhouse Gas Emissions from Aircraft, retrieved 16 June 2015, from http://yosemite.epa.gov/opa/admpress.nsf/d0cf6618525a9efb85257359003fb69d/4a0cc9026f4 cbcc285257e60005c15f8!opendocument

FAA (2012). United States Aviation Greenhouse Gas Emissions Reduction Plan, retrieved 16 February 2017, from https://www.faa.gov/about/office_org/headquarters_offices/apl/environ_policy_guidance/polic $\mathrm{y} / \mathrm{media} /$ Aviation_Greenhouse_Gas_Emissions_Reduction_Plan.pdf 
Färe, R., \& Grosskopf, S. (1996). Intertemporal Production Frontiers: With Dynamic DEA. Kluwer Academic, Boston. doi: 10.1007/978-94-009-1816-0

Färe, R., Grosskopf, S., \& Hernandez-Sancho, F. (2004). Environmental Performance: An Index Number Approach. Resource and Energy Economics, 26, 343-352. doi: http://dx.doi.org/10.1016/j.reseneeco.2003.10.003

Färe, R., Grosskopf, S., Lovell, C. A. K., \& Pasurka, C. (1989). Multilateral Productivity Comparisons When Some Outputs are Undesirable: A Nonparametric Approach. The Review of Economics and Statistics, 71(1), 90-98. doi: http://dx.doi.org/10.2307/1928055

Färe, R., Grosskopf, S., \& Pasurka, C. (1986). Effects on relative efficiency in electric power generation due to environmental controls. Resources and Energy, 8(2), 167-184. doi: http://dx.doi.org/10.1016/0165-0572(86)90016-2

Farrell, M. J. (1957). The Measurement of Productive Efficiency. Journal of the Royal Statistical Society Series a-General, 120(3), 253-290. doi: http://dx.doi.org/10.2307/2343100

Førsund, F. R. (2009). Good Modelling of Bad Outputs: Pollution and Multiple-Output Production. International Review of Environmental and Resource Economics, 3(1), 1-38. doi: http://dx.doi.org/10.1561/101.00000021

Førsund, F.R. (2017). Multi-equation Modelling of Desirable and Undesirable Outputs Satisfying the Materials Balance. Empirical Economics, 1-33. doi: 10.1007/s00181-016-1219-9

Frisch, R. (1965). Theory of Production: Dordrecht Reidel Publishing Company.

Fukuyama, H., Yoshida, Y., \& Managi, S. (2011). Modal choice between air and rail: a social efficiency benchmarking analysis that considers $\mathrm{CO}_{2}$ emissions. Environmental Economics and Policy Studies, 13(2), 89-102. doi: http://dx.doi.org/10.1007/s10018-010-0006-7

Good, D., Nadiri, M., Roller, L. H., \& Sickles, R. C. (1993). Efficiency and productivity growth comparisons of European and US air carriers: A first look at the data. Journal of Productivity Analysis, 4, 115-125. doi: http://dx.doi.org/10.1007/BF01073469.

Good, D. H., Röller, L. H., \& Sickles, R. C. (1995). Airline efficiency differences between Europe and the US: Implications for the pace of EC integration and domestic regulation. European Journal of Operational Research, 80(3), 508-518. doi: 10.1016/0377-2217(94)00134-X

Gössling, S., Peeters, P., \& Scott, D. (2008). Consequences of Climate Policy for International Tourist Arrivals in Developing Countries. Third World Quarterly, 29(5), 873-901. doi: http://dx.doi.org/10.1080/01436590802106007

Greer, M. (2006). Are the discount carriers actually more efficient than the legacy carriers? A data envelopment analysis. International Journal of Transport Economics, 33(1), 37-55. doi: http://www.jstor.org/stable/42747777

Greer, M. (2008). Nothing focuses the mind on productivity quite like the fear of liquidation: Changes in airline productivity in the United States, 2000-2004. Transportation Research Part A: Policy and Practice, 42(2), 414-426. doi: http://dx.doi.org/10.1016/j.tra.2007.11.001

Greer, M. (2009). Is it the labor unions' fault? Dissecting the causes of the impaired technical efficiencies of the legacy carriers in the United States. Transportation Research Part A: Policy and Practice, 43(9/10), 779-789. doi: http://dx.doi.org/10.1016/j.tra.2009.07.007

Greer, M. (2016). Airline Mergers in the United States since 2005: What Impact Have They Had on Airline Efficiency?, in Bitzan, J. D., Peoples, J. H., \& Wilson, W. W. (ed.). Airline Efficiency (Advances in Airline Economics, Volume 5), Emerald Group Publishing Limited, 161-195. doi: $10.1108 /$ S2212-160920160000005007

Hong, S., \& Zhang, A. (2010). An efficiency study of airlines and air cargo/passenger divisions: A DEA approach. World Review of Intermodal Transportation Research, 3, 137-149. doi: http://dx.doi.org/10.1504/WRITR.2010.031584 
IATA (2013). IATA Annual Review 2013, retrieved 15 October 2014, from http://www.iata.org/about/Documents/iata-annual-review-2013-en.pdf

IATA (2016). IATA Fact Sheet - Fuel, retrieved 16 February 2017, from http://www.iata.org/pressroom/facts_figures/fact_sheets/Documents/fact-sheet-fuel.pdf ICAP (2015).

ICAP (2015) Emissions Trading Worldwide-International Carbon Action Partnership (ICAP)-Status Report 2015, retrieved 25 June 2015, from (https://icapcarbonaction.com/images/StatusReport2015/ICAP_Report_2015_02_10_online_v ersion.pdf)

Inglada, V., Rey, B., Rodríguez-Alvarez, A., \& Coto-Millan, P. (2006). Liberalisation and efficiency in international air transport. Transportation Research Part A: Policy and Practice, 40(2), 95105. doi: http://dx.doi.org/10.1016/j.tra.2005.04.006

IPCC (2007). Working Group 1: The Physical Basis of Climate Change, Final Report. Paris: IPCC.

Kerstens, K., \& Van de Woestyne, I. (2014). Comparing Malmquist and Hicks-Moorsteen productivity indices: Exploring the impact of unbalanced vs. balanced panel data. European Journal of Operational Research, 233(3), 749-758. doi: http://dx.doi.org/10.1016/j.ejor.2013.09.009

Lee, B. L., Wilson, C., \& Pasurka, C. A. (2015). The good, the bad, and the efficient: Productivity, efficiency, and technical change in the airline industry, 2004-11, Journal of Transport Economics and Policy, 49(2), 338-354.

Lee, B. L., Wilson, C., \& Pasurka, C. A. (2016). Sources of airline productivity from carbon emissions: An analysis of operational performance under good and bad outputs. Journal of Productivity Analysis, doi: 10.1007/s11123-016-0480-4

Lee, B. L., \& Worthington, A. C. (2014). Technical efficiency of mainstream airlines and low-cost carriers: New evidence using bootstrap data envelopment analysis truncated regression. Journal of Air Transport Management, 38, 15-20. doi: http://dx.doi.org/10.1016/j.jairtraman.2013.12.013

Li, Y., Wang, Y., \& Cui, Q. (2015). Evaluating airline efficiency: an application of virtual frontier network SBM. Transportation Research Part E: Logistics and Transportation Review, 81, 1 17. doi: http://dx.doi.org/10.1016/j.tre.2015.06.006

Li, Y., Wang, Y., \& Cui, Q. (2016a). Has airline efficiency affected by the inclusion of aviation into European Union Emission Trading Scheme? Evidences from 22 airlines during 2008-2012. Energy, 96, 8-22. doi: http://dx.doi.org/10.1016/j.energy.2015.12.039

Li, Y., Wang, Y., \& Cui, Q. (2016b). Energy efficiency measures for airlines: An application of virtual frontier dynamic range adjusted measure. Journal of Renewable and Sustainable Energy, 8(015901). doi: http://dx.doi.org/10.1063/1.4938221.

Lovell, C. A. K. (2003). The decomposition of Malmquist productivity indexes. Journal of Productivity Analysis, 20(3), 437-458. doi: http://dx.doi.org/10.1023/a:1027312102834

Mallikarjun, S. (2015). Efficiency of US airlines: A strategic operating model. Journal of Air Transport Management, 2015, 43, 46-56. doi: http://dx.doi.org/10.1016/j.jairtraman.2014.12.004

Merkert, R., \& Hensher, D. A. (2011). The impact of strategic management and fleet planning on airline efficiency: A random effects Tobit model based on DEA efficiency scores. Transportation Research Part A: Policy and Practice, 45(7), 686-695. doi: http://dx.doi.org/10.1016/j.tra.2011.04.015

Morrell, P. S., \& Taneja, N. K. (1979). Airline productivity redefined: An analysis of US and European carriers. Transportation, 8(1), 37-49. doi: 10.1007/BF00149850 
Murty, S. (2010). On the theory of a firm: the case of by-production of emissions. Working Paper. Coventry: University of Warwick. Dept. of Economics. Warwick economics research paper series (TWERPS), 2010 (934), 1-45. doi: http://wrap.warwick.ac.uk/3525/

Murty, S., Robert Russell, R., \& Levkoff, S. B. (2012). On modeling pollution-generating technologies. Journal of Environmental Economics and Management, 64(1), 117-135. doi: http://dx.doi.org/10.1016/j.jeem.2012.02.005

O’Donnell, C. J. (2008). An aggregate quantity-price framework for measuring and decomposing productivity and profitability change. Working Papers WP07/2008: School of Economics, University of Queensland, Australia.

O'Donnell, C. J. (2010). Measuring and decomposing agricultural productivity and profitability change. Australian Journal of Agricultural and Resource Economics, 54(4), 527-560. doi: http://dx.doi.org/10.1111/j.1467-8489.2010.00512.x

O’Donnell, C. J. (2012). An aggregate quantity framework for measuring and decomposing productivity change. Journal of Productivity Analysis, 38(3), 255-272. doi: http://dx.doi.org/10.1016/10.1007/s11123-012-0275-1

Ouellette, P., Petit, P., Tessier-Parent, L. P., \& Vigeant, S. (2010). Introducing regulation in the measurement of efficiency, with an application to the Canadian air carriers industry. European Journal of Operational Research, 200, 216-226. doi: 10.1016/j.ejor.2008.11.041

Oum, T. H., \& Yu, C. (1995). A productivity comparison of the world's major airlines. Journal of Air Transport Management, 2(3/4), 181-195. doi: http://dx.doi.org/10.1016/0969-6997(96)000075

Ray, S. C. (2008). The Directional Distance Function and Measurement of Super-Efficiency: An Application to Airlines Data. The Journal of the Operational Research Society, 59(6), 788797. doi: http://www.jstor.org/stable/30133000

Ray, S. C., \& Mukherjee, K. (1996). Decomposition of the fisher ideal index of productivity: A nonparametric dual analysis of US airlines data. The Economic Journal, 106, 1659-1678. doi: http://www.jstor.org/stable/2235206

Reklev, S. (2015). South Korea launches world's second-biggest carbon market, retrieved 23 June 2015, from http://in.reuters.com/article/2015/01/12/southkorea-carbontradingidINKBN0KL05K20150112

Schefczyk, M. (1993). Operational performance of airlines: An extension of traditional measurement paradigms. Strategic Management Journal, 14(4), 301-317. doi: http://dx.doi.org/10.1002/smj.4250140406

Schmidt, P., \& Sickles, R. C. (1984). Production frontiers and panel data. Journal of Business and Economic Statistics, 2(4), 367-374. doi: http://www.jstor.org/stable/1391278

Serra, T., Chambers, R. G., \& Oude Lansink, A. (2014). Measuring technical and environmental efficiency in a state-contingent technology. European Journal of Operational Research, 236(2), 706-717. doi: http://dx.doi.org/10.1016/j.ejor.2013.12.037

Sgouridis, S., Bonnefoy, P. A., and Hansman, R. J. (2011). Air transportation in a carbon constrained world: Long-term dynamics of policies and strategies for mitigating the carbon footprint of commercial aviation," Transportation Research Part A: Policy and Practice, 45, 1077-1091. doi: 10.1016/j.tra.2010.03.019

Sickles, R. C., Good, D. H., \& Getachew, L. (2002). Specification of distance functions using semiand nonparametric methods with an application to the dynamic performance of eastern and western European air carriers. Journal of Productivity Analysis, 17(1-2), 133-155. doi: 10.1023/A:1013592506555 
Wang, W. K., Lu, W. M., \& Tsai, C. J. (2011). The relationship between airline performance and corporate governance amongst US Listed companies. Journal of Air Transport Management, 17(2), 148-152. doi: http://dx.doi.org/10.1016/j.jairtraman.2010.06.005

Wanke, P., \& Barros, C. P. (2016). Efficiency in Latin American airlines: A two-stage approach combining Virtual Frontier Dynamic DEA and Simplex Regression. Journal of Air Transport Management, 54, 93-103. doi: 10.1016/j.jairtraman.2016.04.001

Windle, R. J. (1991). The World's Airlines: A cost and productivity comparison. Journal of Transport, Economics and Policy, 25, 31-49. doi: http://www.jstor.org/stable/20052937

Xu, X., \& Cui, Q. (2017). Evaluating airline energy efficiency: An integrated approach with Network Epsilon-based Measure and Network Slacks-based Measure. Energy, 122, 274-286. doi: http://dx.doi.org/10.1016/j.energy.2017.01.100

Yang, C., \& Wang, T. P. (2016). Productivity comparison of European airlines: Bootstrapping Malmquist indices. Applied Economics, 48(52), 5106-5116. doi: 10.1080/00036846.2016.1170937

Yang, S., \& Zhao, T. (2015). Research on Chinese Emissions Trading System Pilots. Paper presented at the Advanced Materials Research.

Yu, C. (2016). Airline Productivity and Efficiency: Concept, Measurement, and Applications, in Bitzan, J. D., Peoples, J. H., \& Wilson, W. W. (ed.). Airline Efficiency (Advances in Airline Economics, Volume 5), Emerald Group Publishing Limited, 11-53. doi: 10.1108/S2212160920160000005002

Zhang, Z. (2015). Crossing the river by feeling the stones: the case of carbon trading in China. Environmental Economics and Policy Studies, 17(2), 263-297. doi: http://dx.doi.org/10.1007/s10018-015-0104-7

Zhou, P., Ang, B. W., \& Poh, K. L. (2008). A survey of data envelopment analysis in energy and environmental studies. European Journal of Operational Research, 189(1), 1-18. doi: http://dx.doi.org/10.1016/j.ejor.2007.04.042 